\title{
Denitrification and inference of nitrogen sources in the karstic Floridan Aquifer
}

\author{
J. B. Heffernan ${ }^{1,2, *}$, A. R. Albertin ${ }^{3}$, M. L. Fork ${ }^{1}$, B. G. Katz ${ }^{4}$, and M. J. Cohen ${ }^{3}$ \\ ${ }^{1}$ Department of Biological Sciences, Florida International University, Miami, FL, USA \\ ${ }^{2}$ Southeast Environmental Research Center, Florida International University, Miami, FL, USA \\ ${ }^{3}$ School of Forest Resources and Conservation, University of Florida, Gainesville, FL, USA \\ ${ }^{4}$ US Geological Survey, Tallahasee, FL, USA \\ *present address: Nicholas School of the Environment, Duke University, Durham, NC, USA
}

Correspondence to: J. B. Heffernan (james.heffernan@duke.edu)

Received: 26 September 2011 - Published in Biogeosciences Discuss.: 20 October 2011

Revised: 1 April 2012 - Accepted: 10 April 2012 - Published: 11 May 2012

\begin{abstract}
Aquifer denitrification is among the most poorly constrained fluxes in global and regional nitrogen budgets. The few direct measurements of denitrification in groundwaters provide limited information about its spatial and temporal variability, particularly at the scale of whole aquifers. Uncertainty in estimates of denitrification may also lead to underestimates of its effect on isotopic signatures of inorganic $\mathrm{N}$, and thereby confound the inference of $\mathrm{N}$ source from these data. In this study, our objectives are to quantify the magnitude and variability of denitrification in the Upper Floridan Aquifer (UFA) and evaluate its effect on $\mathrm{N}$ isotopic signatures at the regional scale. Using dual noble gas tracers ( $\mathrm{Ne}, \mathrm{Ar}$ ) to generate physical predictions of $\mathrm{N}_{2}$ gas concentrations for 112 observations from 61 UFA springs, we show that excess (i.e. denitrification-derived) $\mathrm{N}_{2}$ is highly variable in space and inversely correlated with dissolved oxygen $\left(\mathrm{O}_{2}\right)$. Negative relationships between $\mathrm{O}_{2}$ and $\delta^{15} \mathrm{~N}_{\mathrm{NO}}$ across a larger dataset of 113 springs, well-constrained isotopic fractionation coefficients, and strong ${ }^{15} \mathrm{~N}:{ }^{18} \mathrm{O}$ covariation further support inferences of denitrification in this uniquely organic-matter-poor system. Despite relatively low average rates, denitrification accounted for $32 \%$ of estimated aquifer $\mathrm{N}$ inputs across all sampled UFA springs. Back-calculations of source $\delta^{15} \mathrm{~N}_{\mathrm{NO} 3}$ based on denitrification progression suggest that isotopically-enriched nitrate $\left(\mathrm{NO}_{3}^{-}\right)$in many springs of the UFA reflects groundwater denitrification rather than urban- or animal-derived inputs.
\end{abstract}

\section{Introduction}

Anthropogenic increases in reactive nitrogen $(\mathrm{N})$ availability have wide-ranging consequences including eutrophication of aquatic systems, acidification of soils and surface waters, loss of biodiversity, and facilitation of disease transmission (Vitousek, 1994; Galloway et al., 2003; Smith and Schindler, 2009). Denitrification, which reduces $\mathrm{NO}_{3}^{-}$to $\mathrm{N}_{2}$ gas, mitigates this enrichment by returning $\mathrm{N}$ to long-residence-time atmospheric pools, and is an important component of the nitrogen cycle at local, regional, and global scales (David et al., 2006; Seitzinger et al., 2006; Townsend and Davidson, 2006; Schlesinger, 2009; Sigman et al., 2009). Although denitrification was once thought to occur only via the oxidation of simple organic compounds, more recent work has demonstrated that $\mathrm{NO}_{3}^{-}$reduction can involve multiple electron donors and end products (Burgin and Hamilton, 2007). Patchy and ephemeral distribution, diverse reaction modes, and challenges of direct measurement of $\mathrm{N}_{2}$ all contribute to persistent high uncertainty in local, regional, and global estimates of denitrification (Davidson and Seitzinger, 2006; Groffman et al., 2009).

Aquifer denitrification is a potentially large component of regional and global nitrogen $(\mathrm{N})$ budgets, with a recent global estimate of $44 \mathrm{Tg} \mathrm{N} \mathrm{yr}^{-1}$ (16\% of land-based annual $\mathrm{N}$ inputs; Seitzinger et al., 2006). However, existing estimates are based on simple models and are extremely poorly constrained (range of estimates from Seitzinger et al., (2006): 0$138 \mathrm{Tg} \mathrm{N} \mathrm{yr}^{-1}$ ), in large part due to the limited number and 
spatio-temporal extent of available direct measurements of denitrification. Additional uncertainty arises because existing studies of groundwater $\mathrm{N}$ concentrations and denitrification are potentially biased by preferential study of aquifers with high $\mathrm{N}$ loading and high rates of denitrification (Green et al., 2008; Schlesinger, 2009). Moreover, measures of denitrification based on nitrate loss appear to provide much higher estimates than those based on direct measurement of $\mathrm{N}_{2}$ gas accumulation (Green et al., 2008). Despite their limited numbers, directly-measured aquifer denitrification rates nonetheless span several orders of magnitude, and associated reductions in $\mathrm{NO}_{3}^{-}$range from negligible to complete across aquifer systems (Green et al., 2008). The extent to which these outcomes vary in space and time within individual aquifers is poorly understood.

Estimation of denitrification from $\mathrm{N}_{2}$ gas concentrations in groundwaters requires determination of physical parameters (recharge temperature $\left[\mathrm{T}_{\text {rec }}\right]$ and excess air $\left[\mathrm{A}_{\mathrm{ex}}\right]$ ) that influence the quantity and composition of dissolved gases (Vogel et al., 1981; Wilson and McNeill, 1997; Cey et al., 2009). Recharge temperature, rather than ambient temperature at the time of sample collection, is what determines the solubility of atmospheric gases at the time when infiltrating groundwater loses contact with the atmosphere. Depending on the seasonality of temperature, precipitation, and infiltration, as well as other factors, recharge temperatures can diverge substantially from mean annual air temperatures (Hall et al., 2005; Castro et al., 2007). Dissolution of excess air occurs when bubbles of atmospheric air are entrained beneath the saturated zone; supersaturation of gases with respect to surface conditions is enabled by hydrostatic pressure at depth. Direct simultaneous estimation of these parameters requires two tracers (typically noble gases; Feast et al., 1998; Cey et al., 2009), but most measurements of $\mathrm{N}_{2}$ are made only in conjunction with $\operatorname{Ar}$ (Kana et al., 1994). Studies that estimate denitrification via direct measurement of $\mathrm{N}_{2}$ thus typically rely on assumed constant values of either recharge temperature or excess air entrainment to estimate biologically-derived $\mathrm{N}_{2}$ (e.g. Green et al., 2008). Since recharge temperature and excess air entrainment can vary at broad scales due to variation in climate and geological structure, assessment of denitrification at regional or broader scales requires estimation of these physical parameters for each study site.

Across diverse ecosystems, availability of organic matter is the primary driver of denitrification (Taylor and Townsend, 2010). Within ecosystems, spatial and temporal variability in the concentration of organic matter and nitrate and anoxic conditions produce heterogeneous mosaics of denitrifying activity (e.g. Harms and Grimm, 2008). In groundwater environments with strong directional flow, denitrification and other redox processes can follow distinctive spatial patterns reflecting the gradual downstream depletion of electron donors and acceptors (Chapelle et al., 1995; Hedin et al., 1998; Tarits et al., 2006). However, a growing body of research suggests that denitrification in most aquifers depends on matrix-derived, solid-phase electron donors (e.g. $\mathrm{Fe}^{2+}$, $\mathrm{H}_{2} \mathrm{~S}$ ) rather than surface-derived solutes (Green et al., 2008; Schwientek et al., 2008; Zhang et al., 2009; Torrento et al., 2010, 2011). As a result, concentrations of dissolved organic matter and other electron donors may be a poor indicator of denitrification rates across aquifers, and spatial patterns within aquifers may reflect the distribution of these reactants within the aquifer matrix rather than substrate depletion along advective flowpaths.

Efforts to understand and manage $\mathrm{N}$ enrichment of aquatic ecosystems have relied heavily on the distinctive isotopic signatures of potential sources (Kendall, 1998; Kendall et al., 2007), particularly the difference in $\delta^{15} \mathrm{~N}_{\mathrm{NO} 3}$ between inorganic fertilizers (typically $0-3 \%$ ) and organic $\mathrm{N}$ pools (i.e. animal and human waste; typically 9-12\%o). More recently, methodological developments that permit determination of both $\mathrm{N}$ and $\mathrm{O}$ allow greater separation of sources with overlapping $\delta^{15} \mathrm{~N}$ signatures (e.g. atmospheric deposition and synthetic fertilizer). Biogeochemical reactions such as denitrification and assimilation can alter these isotopic signatures during transport, potentially confounding $\mathrm{N}$ source inference (Kendall et al., 2007). Despite pleas for caution (Bedard-Haughn et al., 2003), observed $\delta^{15} \mathrm{~N}_{\mathrm{NO}}$ are commonly used to infer $\mathrm{N}$ sources and guide management and policy related to point and non-point inputs (Fogg et al., 1998; USGS, 2003; Harrington et al., 2010). While the potential effect of denitrification on isotope signatures is widely acknowledged, few studies to date have quantified its influence on source inference at the scale of a regional aquifer (but see McMahon and Bohlke 2006).

In addition to their utility in separating potentially confounded $\mathrm{N}$ sources, dual isotopic tracers $\left(\delta^{15} \mathrm{~N}_{\mathrm{NO} 3}\right.$ and $\left.\delta^{18} \mathrm{O}_{\mathrm{NO} 3}\right)$ of $\mathrm{NO}_{3}^{-}$can also be used to infer nitrogen transformations. Although insufficient to directly estimate rates of denitrification, coupled enrichment of $\delta^{15} \mathrm{~N}_{\mathrm{NO} 3}$ and $\delta^{18} \mathrm{O}_{\mathrm{NO} 3}$ is now widely used to infer the occurrence of fractionating processes (Burns et al., 2009). Among these are recent studies that suggest denitrification in the Upper Floridan Aquifer and other karst groundwater systems (Panno et al., 2001; Hackley et al., 2007; Albertin et al., 2011). One potential value of dual isotopic measurements is the ability to partition removal into its component processes (e.g. assimilation, denitrification) based on the ratio of ${ }^{15} \mathrm{~N}:{ }^{18} \mathrm{O}$ enrichment. Theoretical and laboratory studies have suggested that denitrification results in 2:1 fractionation of ${ }^{15} \mathrm{~N}:{ }^{18} \mathrm{O}$ (Aravena and Robertson, 1998; Lehmann et al., 2003), but other studies have recently suggested a 1:1 ratio (Granger et al., 2008), in which case dual isotopes would be unable to distinguish between assimilation and denitrification.

In this study, our objectives are (1) to quantify the magnitude and variability of denitrification at the regional scale in a karstic groundwater system (the Upper Floridan Aquifer [UFA]), and (2) to assess the influence of denitrification on isotopic signatures of nitrate in the UFA and its influence on apparent $\mathrm{N}$ sources. To these ends, we measured dissolved 
gases and other biogeochemical characteristics of 35 Florida springs, conducted a 3 year study (quarterly-monthly samples) of 6 springs that feed the Ichetucknee River, and assembled published data describing dissolved gas concentration, nutrient chemistry, and/or nitrate isotope composition from over 100 additional springs. From a subset of 31 of these springs for which dual noble gas tracers ( $\mathrm{Ne}$ and $\mathrm{Ar}$ ) were available, we derived statistical predictors of excess air entrainment. These data enable an extensive and robust assessment of denitrification and its influence on nitrate isotopic composition at the scale of the entire UFA.

\section{Methods}

\subsection{Study system}

The karstic Upper Floridan Aquifer (UFA) supports the highest density of large natural artesian springs in the world (Fig. 1), and is a major regional economic resource (Notholt et al., 1989; Miller, 1990; Bonn and Bell, 2003; Bonn, 2004). Throughout parts of northern Florida, the UFA is confined by low-permeability, high-clay deposits that preclude infiltration to the UFA except via sinkholes and fractures; these confining layers are largely absent in the central-western portion of the state (Scott et al., 2004). Springs are concentrated along drainage features, especially near boundaries of confining layers. Land use throughout the study region includes variable mixtures of row crop agriculture, urban and suburban development, and secondary forest (Katz et al., 2001).

Geochemistry of the UFA can generally be characterized as a mixture of two end members (Toth and Katz, 2006; Knowles et al., 2010). Older water, characteristic of matrix porosity and deep flowpaths, is generally anoxic, low in $\mathrm{NO}_{3}^{-}$, and enriched in calcium; younger water characteristic of conduits and shallower flowpaths is generally oxic, enriched in $\mathrm{NO}_{3}^{-}$, and sometimes subsaturated in calcium (Toth and Katz, 2006; Knowles et al., 2010). Over event-driven and decadal timescales, the contribution of these water sources can vary considerably among springs as changes in flow drive exchange between primary and secondary porosity (i.e. the limestone matrix and karst conduits; Martin and Dean, 2001; Heffernan et al., 2010a, b). Except during runoff and backflow events that deliver organic-matter-rich waters to conduits (Gulley et al., 2011), dissolved organic carbon (DOC) levels in UFA springs are among the lowest measured globally (Duarte et al., 2010). In conjunction with oxic conditions of many springs, low DOC concentrations undoubtedly contribute to the prevailing assumption that denitrification is negligible in this system (Katz, 2004).

$\mathrm{NO}_{3}^{-}$concentrations in the UFA and its springs have risen dramatically over the past half-century (e.g. Upchurch et al., 2007), and springs discharge accounts for a large proportion of the $\mathrm{N}$ load to estuarine and coastal waters (Pittman et al., 1997). Despite the perceived vulnerability of the UFA to nutrient enrichment, river export accounts for only a moderate proportion of $\mathrm{N}$ inputs to North Florida landscapes, and considerable proportions of inputs remain unaccounted for (Katz et al., 2009). Landscape-scale mass balance generally suggests inorganic fertilizer as the primary source of $\mathrm{N}$ enrichment (Katz et al., 2009), but isotopic studies (that assumed negligible denitrification) have indicated a greater role of organic $\mathrm{N}$ from animal or human waste water (Katz et al., 2001).

\subsection{Sample collection and analysis}

Between June and September 2010, we sampled 33 Floridan Aquifer springs that varied in size, surficial hydrogeology, and $\mathrm{NO}_{3}^{-}$and $\mathrm{O}_{2}$ concentrations. At each spring, we measured $\mathrm{O}_{2}$, temperature, specific conductance, and $\mathrm{pH}$ from spring vents using a YSI 556 sonde equipped with an optical or Clark $\mathrm{O}_{2}$ probe. Water samples for laboratory analyses were collected using a peristaltic pump with a $5 \mathrm{~m}$ weighted intake tube placed as near as possible to the spring vent. We collected 3 replicate samples for nutrient and isotopic analyses in acid-washed pre-rinsed polyethylene bottles. During the synoptic survey, we collected 5 replicate field samples for dissolved gas analysis by flushing $300 \mathrm{ml}$ BOD bottles 3 times, sealing with glass stopper, and capping with waterfilled plastic caps to minimize exchange with atmosphere and to prevent stoppers from becoming dislodged during transport. Dissolved gas samples were stored under ice water until analysis within 36 hours; water samples were frozen until analysis.

We measured dissolved $\mathrm{N}_{2}$ and Ar using a Membrane Inlet Mass Spectrometer (MIMS: Kana et al., 1994) within 36 hours of collection, over which period our storage protocol exhibited negligible atmospheric contamination. The membrane inlet mass spectrometer was equipped with a copper reduction column heated to $600^{\circ} \mathrm{C}$ to remove $\mathrm{O}_{2}$ and reduce interference with $\mathrm{N}_{2}$ measurements (Eyre et al., 2002). Standards for $\mathrm{N}_{2}$ and $\mathrm{Ar}$ concentration consisted of atmosphereequilibrated deionized water in $1 \mathrm{~L}$ spherical vessels incubated and stirred in high-precision water baths $\left( \pm 0.01^{\circ} \mathrm{C}\right)$ at their respective temperatures $\left(10,15\right.$, and $\left.20^{\circ} \mathrm{C}\right)$ for at least 24 hours prior to analysis. Gas concentrations in each standard were calculated using temperature-solubility formulas without salinity correction (Hamme and Emerson, 2004). Signal strength for samples and standards was determined as the mean value of the 1 st minute following signal stabilization. To account for instrument drift, we ran complete standard curves every 6-8 samples and applied interpolated parameter values from adjacent standard curves $\left(r^{2}\right.$ range: 0.997-1.00; mean $\left.r^{2}=0.9997\right)$ to estimate gas concentrations in each sample. A fourth standard equilibrated with pure $\mathrm{N}_{2}$ gas served as an external source QC. Coefficients of variation for field replicates ranged from $0.22-2.27 \%$ (mean: $0.80 \%$; median: $0.49 \%$ ). 


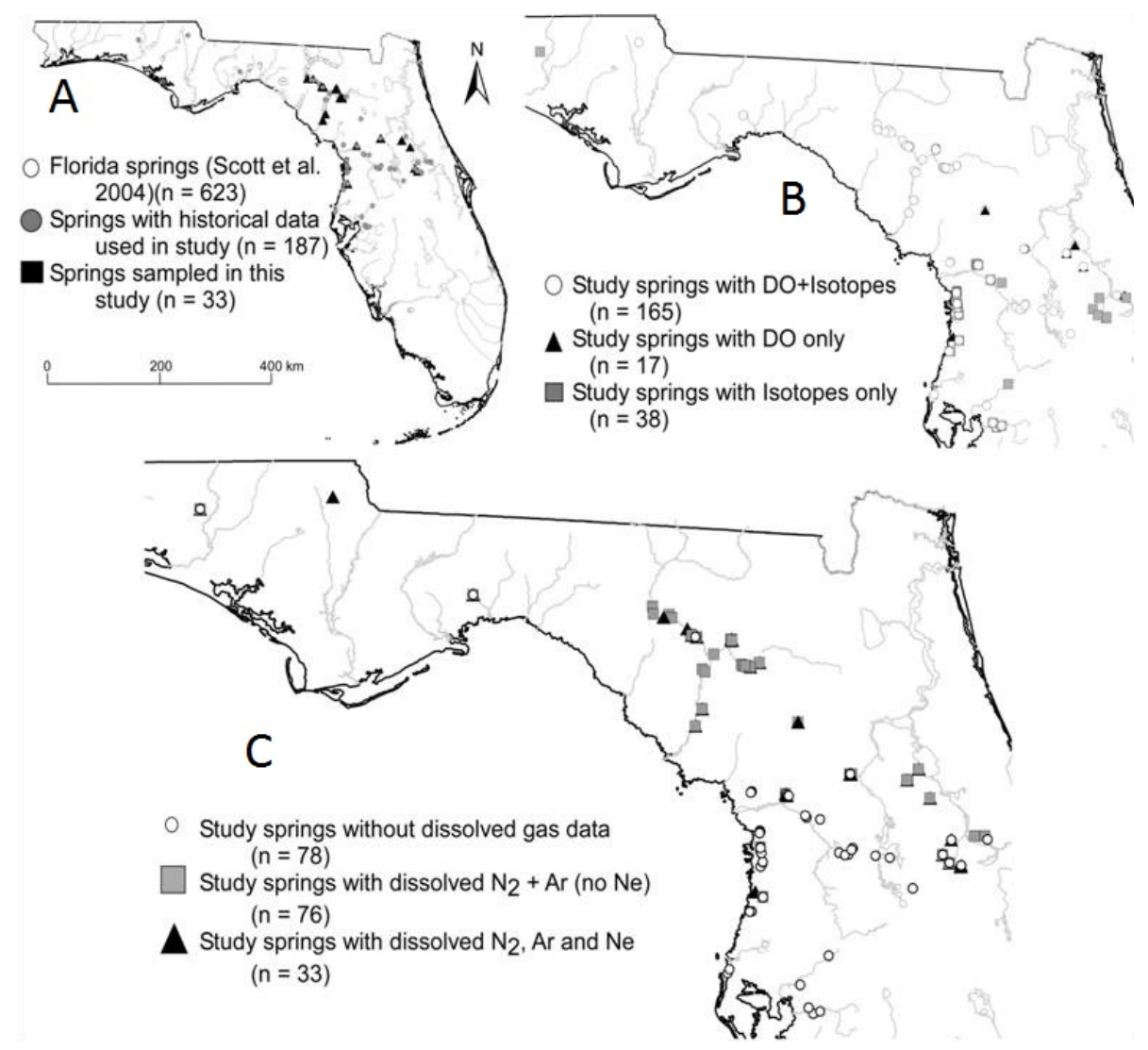

Fig. 1. Geographic distribution of Florida springs and observations sets used in this study. Panels illustrate (A) distribution of study sites (closed symbols) in comparison to distribution of all named springs, (B) distribution of study springs with and without isotopic measurements, and (C) distribution of study sites without dissolved gas data, with $\mathrm{O}_{2}, \mathrm{Ar}$, and $\mathrm{N}_{2}$, and with additional observation of $\mathrm{Ne}$.

We measured nitrate concentrations (expressed in this paper in $\mathrm{m} \mathrm{NL}^{-1}$ ) in samples from the synoptic survey and Ichetucknee River springs time series using secondderivative UV spectroscopy (APHA et al., 2005) using an Aquamate UV-Vis spectrometer. Isotopic composition of nitrate $\left(\delta^{15} \mathrm{~N}_{\mathrm{NO} 3}, \delta^{18} \mathrm{O}_{\mathrm{NO} 3}\right)$ was measured using the bacterial denitrifier method (Sigman et al., 2001; Casciotti et al., 2002) in the Department of Geological Sciences at the University of Florida (2007-2009) or the UC-Riverside Facility for Isotope Ratio Mass Spectrometry (2010).

Previously-collected data both increased spatial coverage and in many cases provided repeated measurements of springs included in our synoptic survey (Fig. 1). Measurements of $\mathrm{Ne}, \mathrm{Ar}, \mathrm{N}_{2}, \mathrm{O}_{2}, \mathrm{NO}_{3}^{-}$, and nitrate isotopes $\left(\delta^{15} \mathrm{~N}_{\mathrm{NO} 3}, \delta^{18} \mathrm{O}_{\mathrm{NO} 3}\right)$ spanning from 1997 to 2008 were obtained from published articles and agency reports, or directly from researchers when dissolved gas concentration or other data were not reported directly (see supplemental materials). Thirty-six archival observations (from 31 springs) included $\mathrm{Ne}$ in addition to $\mathrm{Ar}, \mathrm{O}_{2}$, and $\mathrm{N}_{2}$ (and in 23 cases $\delta^{15} \mathrm{~N}_{\mathrm{NO}}$ ). In all, we assembled 112 observations of dissolved gas concentrations $\left(\mathrm{O}_{2}, \mathrm{Ar}, \mathrm{N}_{2}\right)$ from 62 distinct spring vents, of which 58 included both $\delta^{15} \mathrm{~N}_{\mathrm{NO} 3}$ and $\delta^{18} \mathrm{O}_{\mathrm{NO} 3}$, and 34 others included $\delta^{15} \mathrm{~N}_{\mathrm{NO} 3}$ but not $\delta^{18} \mathrm{O}_{\mathrm{NO} 3}$. Excluding the repeated measurements of the Ichetucknee River springs in 20082009 , our data included 166 observations of $\delta^{15} \mathrm{~N}_{\mathrm{NO} 3}$ and $\mathrm{O}_{2}$ and 204 total observations of $\delta^{15} \mathrm{~N}_{\mathrm{NO} 3}$. Of the 113 springs represented in the isotope data set, 14 had 4 or more instances of concurrent measurements of both $\mathrm{O}_{2}$ and $\delta^{15} \mathrm{~N}_{\mathrm{NO} 3}$. Observations were drawn from springs in each major drainage in North and Central Florida (Fig. 1), and with discharges ranging from $<0.01 \mathrm{~m}^{3} \mathrm{~s}^{-1}$ to $11 \mathrm{~m}^{3} \mathrm{~s}^{-1}$. Because noble gas concentration data are used to assess contamination of ${ }^{3} \mathrm{H} /{ }^{3} \mathrm{He}$ samples, we were also able to obtain data describing ${ }^{3} \mathrm{H} /{ }^{3} \mathrm{He}$ water age for 36 springs from the same sources that provided Ne data (see Supplement).

All measurements of $\mathrm{Ne}$ from prior studies were determined by mass spectrometry at the Lamont-Doherty Earth Observatory Noble Gas Laboratory at Columbia University. Nitrate (as $\mathrm{NO}_{3}-\mathrm{N}$ ) was generally measured using the cadmium reduction method (Wood et al., 1967). $\mathrm{N}_{2}$ and Ar from previously published studies were measured using gas chromatography. We are unaware of studies that directly compare GC and MIMS methods for measurement of $\mathrm{N}_{2}$ and Ar, but in springs with repeated measurements that included $\mathrm{N}_{2}$ from both methods, we found no evidence of bias between historic 
data and our new observations. Recent (2007 and later) measurements of $\delta^{15} \mathrm{~N}_{\mathrm{NO} 3}$ were generally conducted using the bacterial denitrifier method and included $\delta^{18} \mathrm{O}_{\mathrm{NO} 3}$ (Sigman et al., 2001; Casciotti et al., 2002). For data prior to 2007, $\delta^{15} \mathrm{~N}_{\mathrm{NO} 3}$ was measured via combustion and mass spectrometry (Kendall and Grim, 1990).

\subsection{Springshed characterization}

To determine hydrogeologic predictors of variation among springs in excess air entrainment and recharge temperature, we characterized each spring by latitude, long-term mean discharge, and springshed hydrogeology as measured by aquifer vulnerability to surface contamination (Arthur et al., 2007). We collected discharge records for each spring from online databases of the United States Geological Survey National Water Information System (http: //waterdata.usgs.gov/nwis), Southwest Florida Water Management District (http://www.swfwmd.state.fl.us/data/), and the St. John's River Water Management District (http: //www.sjrwmd.com/toolsGISdata/index.html) where available, since these records were generally the most complete. Where continuous records were unavailable, we used the mean of discrete measurements from published studies and agency reports as our estimate of mean long-term discharge. Since discharge variability of Floridan Aquifer springs is extremely low, use of these more limited data to quantify longterm mean discharge is unlikely to have introduced significant error in subsequent analyses.

Where available, we used previously delineated boundaries (http://www.dep.state.fl.us/geology/programs/ hydrogeology/hydro_resources.htm) to characterize springshed hydrogeology, and to estimate springshed size and location for un-delineated springs. The relationship between discharge and springshed area was determined for those springs with previously delineated springsheds $(A=Q \times$ 134.9 , where $A$ is springshed area in $\mathrm{km}^{2}$ and $Q$ is discharge in $\left.\mathrm{m}^{3} \mathrm{~s}^{-1} ; n=14, r=+0.79, p<0.001\right)$. For springs without a delineated springshed, we estimated the contributing area based on their period-of-record discharge. We assumed each springshed was circular, and estimated the springshed orientation based on the regional drainage network such that the springshed was located with one edge at the spring vent, and the rest up-gradient from the closest spring-fed river.

We used the Floridan Aquifer Vulnerability Assessment (FAVA) as a metric of springshed hydrogeologic characteristics (Arthur et al., 2007). This measure quantifies the intrinsic contamination risk of the Upper Florida Aquifer (UFA) based on local hydrogeologic conditions such as aquifer chemistry, surface soil permeability, surface elevation, subsurface stratigraphy, presence of karst features (e.g. sinkholes) at the surface, thickness of a the intermediate aquifer system that regulates hydraulic confinement of the UFA, and the potentiometric head difference between the surface and UFA (Arthur et al., 2007). Based on these characteristics, regions of the UFA have been designated as "less vulnerable", "vulnerable", and "most vulnerable". We used the areal coverage of these categories as our descriptor of surface-aquifer connectivity. Because none of the springsheds in this study contained more than $3 \%$ of their area in the less vulnerable category, the proportions of "vulnerable" and 'most vulnerable' were highly correlated. We therefore used only the fraction of each springshed area delineated as most vulnerable, typically more than $75 \%$ of the area, as a predictor in our model of excess air entrainment.

\subsection{Estimation of excess air, recharge temperature, and excess $\mathbf{N}_{2}$}

The concentration of $\mathrm{N}_{2}$ gas in groundwater is influenced by physical conditions during infiltration (specifically, recharge temperature $\left[\mathrm{T}_{\mathrm{rec}}\right]$ and excess air entraintment $\left[\mathrm{A}_{\mathrm{ex}}\right]$ ) as well as biological production of $\mathrm{N}_{2}$. We therefore calculated the magnitude of denitrification $\left(\left[\mathrm{N}_{2}\right]_{\text {den }}\right)$ for each sampling date and time as the difference between observed $\mathrm{N}_{2}$ concentrations and the concentration predicted by physical processes ([N $\left.\left.\mathrm{N}_{2}\right]_{\text {phys }}\right)$ :

$\left[\mathrm{N}_{2}\right]_{\text {den }}=\left[\mathrm{N}_{2}\right]_{\text {obs }}-\left[\mathrm{N}_{2}\right]_{\text {phys }}$

We determined concentrations expected based on physical processes, in turn, as the sume of the equilibrium $\mathrm{N}_{2}$ concentration at recharge temperature plus additional $\mathrm{N}_{2}$ dissolved as excess air:

$\left[\mathrm{N}_{2}\right]_{\text {phys }}=k_{\mathrm{N}_{2}} \cdot\left[\mathrm{N}_{2}\right]_{T_{\text {rec }}}+A_{\mathrm{ex}} \cdot P_{\mathrm{N}_{2}}$

where $k_{N 2}$ is a unit conversion factor (from $\mu \mathrm{mol} \mathrm{kg}{ }^{-1}$ to $\left.\mathrm{mg} \mathrm{L}^{-1} ; 0.028\right)$; $\left(\mathrm{N}_{2}\right)_{\text {Trec }}$ is the concentration of $\mathrm{N}_{2}$ at recharge temperature (in $\mu \mathrm{mol} \mathrm{kg}-1$ ); $P_{N 2}$ is the partial pressure of $\mathrm{N}_{2}$ in the atmosphere (0.78084) and $\mathrm{A}_{\mathrm{ex}}$ is the mass of excess air (in $\mathrm{m} \mathrm{L}^{-1}$ ). We used the equations of Hamme and Emmerson (2004) to determine equilibrium $\mathrm{N}_{2}$ concentration $\left(\left[\mathrm{N}_{2}\right]_{\text {Trec }}\right)$ for a given recharge temperature:

$\ln \left(\left[\mathrm{N}_{2}\right]_{T_{\mathrm{rec}}}\right)=A_{0}+A_{1} T_{\mathrm{S}}+A_{2} T_{\mathrm{S}}^{2}+A_{3} T_{\mathrm{S}}^{3}$

where $\mathrm{A}_{0}-\mathrm{A}_{3}$ are compound-specific solubility constants (Table 1 ), and $T_{S}$ is determined as:

$T_{\mathrm{S}}=\ln \left(\frac{298.15-T_{\mathrm{rec}}}{298.15+T_{\mathrm{rec}}}\right)$

We used $\mathrm{Ne}$ and $\mathrm{Ar}$ concentrations to determine recharge temperature $\left[\mathrm{T}_{\mathrm{rec}}\right]$ and excess air $\left[\mathrm{A}_{\mathrm{ex}}\right]$ in the subset $(n=36)$ of springs for which measurements of both gases were available. We estimated these parameters for each observation by simultaneously solving the following equations using the Solver function in Microsoft Excel:

$\begin{array}{ll}{[\mathrm{Ne}]_{\mathrm{obs}}=} & k_{\mathrm{Ne}} \cdot[\mathrm{Ne}]_{T_{\mathrm{rec}}}+A_{\mathrm{ex}} \cdot P_{\mathrm{Ne}} \\ {[\mathrm{Ar}]_{\mathrm{obs}}=} & k_{\mathrm{Ar}} \cdot[\mathrm{Ar}]_{T_{\mathrm{rec}}}+A_{\mathrm{ex}} \cdot P_{\mathrm{Ar}}\end{array}$ 
Table 1. Parameter values for determination of solubilitytemperature relationships for $\mathrm{Ne}, \mathrm{Ar}$, and $\mathrm{N}_{2}$ gas.

\begin{tabular}{llll}
\hline Coefficient & $\mathbf{N e}$ & $\mathbf{A r}$ & $\mathbf{N}_{2}$ \\
\hline $\mathrm{A}_{0}$ & 2.18156 & 2.79150 & 6.42931 \\
$\mathrm{~A}_{1}$ & 1.29108 & 3.17609 & 2.92704 \\
$\mathrm{~A}_{2}$ & 2.12504 & 4.13116 & 4.32531 \\
$\mathrm{~A}_{3}$ & 0 & 4.90379 & 4.69149 \\
\hline
\end{tabular}

where $k_{\mathrm{Ne}}$ and $k_{\mathrm{Ar}}$ are coefficients for unit conversion of $\mathrm{Ne}$ and $\mathrm{Ar}$ from nmol kg${ }^{-1}$ (for $\mathrm{Ne}, k=0.02$ ) or $\mu \mathrm{mol} \mathrm{kg}^{-1}$ (for Ar, $k=0.04)$ to $\mathrm{mg} \mathrm{L}^{-1} ; P_{\mathrm{Ne}}$ and $P_{\mathrm{Ar}}$ are the mass proportion of $\mathrm{Ne}\left(1.81810^{-5}\right)$ and $\mathrm{Ar}\left(9.3410^{-3}\right)$ in the atmosphere; and $[\mathrm{Ne}]_{T r e c}$ and $[\mathrm{Ar}]_{\mathrm{Trec}}$ are the equilibrium concentrations (Hamme and Emerson, 2004) of those gases at the recharge temperature as determined by:

$\begin{array}{ll}\ln \left([\mathrm{Ne}]_{T_{\mathrm{rec}}}\right)= & A_{0}+A_{1} T_{\mathrm{S}}+A_{2} T_{\mathrm{S}}^{2}+A_{3} T_{\mathrm{S}}^{3} \\ \ln \left([\mathrm{Ar}] T_{\mathrm{rec}}\right)= & A_{0}+A_{1} T_{\mathrm{S}}+A_{2} T_{\mathrm{S}}^{2}+A_{3} T_{\mathrm{S}}^{3}\end{array}$

where $T_{S}$ is a function of $\mathrm{T}_{\text {rec }}$ (Eq. 4 ) and values for the $\mathrm{A}_{0^{-}}$ $\mathrm{A}_{3}$ are given in Table 1.

Among this set of springs with $\mathrm{Ne}$ data, estimated $\mathrm{T}_{\text {rec }}$ ranged from $15-22^{\circ} \mathrm{C}$, was overwhelmingly determined by Ar rather than $\mathrm{Ne}$, and varied significantly as a function of latitude (Fig. 2a, b, d). The observed latitudinal variation in $\mathrm{T}_{\text {rec }}$ is much greater than variation in mean annual air temperature, potentially reflecting regional variation in timing of precipitation and thus temperature of infiltrating water (Schmidt et al., 2001).

$\mathrm{A}_{\text {ex }}$ ranged from 1.0 to $2.7 \mathrm{ml} \mathrm{L}^{-1}$ and was overwhelmingly determined by $\mathrm{Ne}$ rather than $\mathrm{Ar}$ (Fig. 2a, b). Based on multiple regression analysis, mean discharge over the period of record $\left(Q_{\mathrm{POR}}\right)$ and springshed vulnerability were strong predictors of excess air (Fig. 2c). Palm spring, whose springshed had no land in the 'most vulnerable' category and was the only value less than $50 \%$, was excluded from this analysis. We used this statistical relationship to estimate $A_{e x}$ in springs for which Ne data were not available. Statistical estimates of $A_{e x}$ constrained solutions for recharge temperature based on Ar concentrations alone (Eqs. 6, 8); $\mathrm{T}_{\mathrm{rec}}$ and $\mathrm{A}_{\mathrm{ex}}$ were then used to determine equilibrium $\mathrm{N}_{2}$ concentrations (Eqs. 3, 4) and denitrification-dervied $\mathrm{N}_{2}$ (Eq. 1).

To test the hypothesis that $\left[\mathrm{N}_{2}\right]_{\text {den }}$ reflects the magnitude of denitrification, we used regression analyses to evaluate the relationship between $\left[\mathrm{N}_{2}\right]_{\text {den }}$ and dissolved $\mathrm{O}_{2}$. We used both linear and logarithmic forms to predict $\left[\mathrm{N}_{2}\right]_{\text {den }}$ from $\mathrm{O}_{2}$, for the entire data set and for the subset of observations in which $\mathrm{A}_{e x}$ was calculated from $\mathrm{Ne}$ data, rather than estimated statistically. We also analyzed the relationship between mean dissolved $\mathrm{O}_{2}$ and mean $\left[\mathrm{N}_{2}\right]_{\text {den }}$ from the subset of springs for which 3 or more observations were available. For the subset of springs for which ${ }^{3} \mathrm{H} /{ }^{3} \mathrm{He}$ ages were available, we estimated zero-order denitrification rates as the concentration of excess $\mathrm{N}_{2}$ divided by water age (Green et al., 2008). Because we lack data for discrete geochemical end-members within each spring, we are unable to quantitatively address the effects of mixing (Green et al., 2010) on our estimates of denitrification rates or $\mathrm{O}_{2}$ thresholds.

To evaluate the relative precision and accuracy of $\left[\mathrm{N}_{2}\right]_{\mathrm{den}}$ estimates based on $\mathrm{Ne}$ and statistically modeled excess air, we calculated the mean and standard deviation of $\left[\mathrm{N}_{2}\right]_{\text {den }}$ estimates for all springs with $\mathrm{O}_{2}$ greater than $2 \mathrm{mg} \mathrm{L}^{-1}$. Bias in estimates would cause divergence of the mean from zero, assuming that denitrification is negligible in these oxic springs (Bohlke et al., 2002; Green et al., 2008).

\subsection{Denitrification progression and isotopic fractionation}

We indirectly evaluated the relationship between denitrification progression and $\delta^{15} \mathrm{~N}_{\mathrm{NO} 3}$ via analysis of relationships between dissolved $\mathrm{O}_{2}$ and $\delta^{15} \mathrm{~N}_{\mathrm{NO} 3}$ both within and across springs, reasoning that springs with lower dissolved $\mathrm{O}_{2}$ would have greater depletion of $\mathrm{NO}_{3}^{-}$pools by denitrification than springs with higher $\mathrm{O}_{2}$. We used both linear and logarithmic regression equations to evaluate dissolved $\mathrm{O}_{2}$ as a predictor of $\delta^{15} \mathrm{~N}_{\mathrm{NO} 3}$ across all observations and excluding observations from the Ichetucknee time series collected between July 2007 and November 2009. Inclusion of the entire Ichetucknee data set had a minimal influence on regression parameters, so only the results from the complete (global) data set are reported here. In addition to this global analysis, we used linear regression to evaluate relationships between dissolved $\mathrm{O}_{2}$ and $\delta^{15} \mathrm{~N}_{\mathrm{NO} 3}$ within springs for which 3 or more observations were available. We then used regression analysis to evaluate how the strength (as measured by the correlation coefficient $(r)$ ) and slope of these within-spring relationships varied as a function of mean dissolved $\mathrm{O}_{2}$. This analysis allowed us to evaluate the contribution of variation within and among springs to patterns seen across all observations.

We directly evaluated the relationship between denitrification progression and isotopic composition of $\mathrm{NO}_{3}^{-}$by determining the fractionation coefficient $\left({ }^{15} \varepsilon\right)$ for $\delta^{15} \mathrm{~N}_{\mathrm{NO} 3}$ from a cross-system analysis that included springs with dissolved gases from both our synoptic survey and previously reported data, and a separate analysis from the Ichetucknee Springs time series (of which most dates did not include dissolved gas measurements). These analyses required estimates of initial $\mathrm{NO}_{3}^{-}$concentration $\left(\left[\mathrm{NO}_{3}^{-}\right]_{\text {init }}\right)$ at the time of recharge, which we estimated using different approaches for springs with dissolved gas data and for the Ichetucknee Springs time series. For analysis of data from the synoptic survey and previous observations that included dissolved gases, we calculated $\left[\mathrm{NO}_{3}^{-}\right]_{\text {init }}$ as the sum of $\left[\mathrm{NO}_{3}^{-}\right]_{\mathrm{obs}}$ and $\left[\mathrm{N}_{2}\right]_{\text {den }}$ (all in units of $\mathrm{m} \mathrm{N} \mathrm{L}^{-1}$ ). This estimate would include nitrate derived from nitrification in the vadose zone or UFA as part of $\left[\mathrm{NO}_{3}^{-}\right]_{\text {init }}$, and assumes that denitrification is the only sink for 

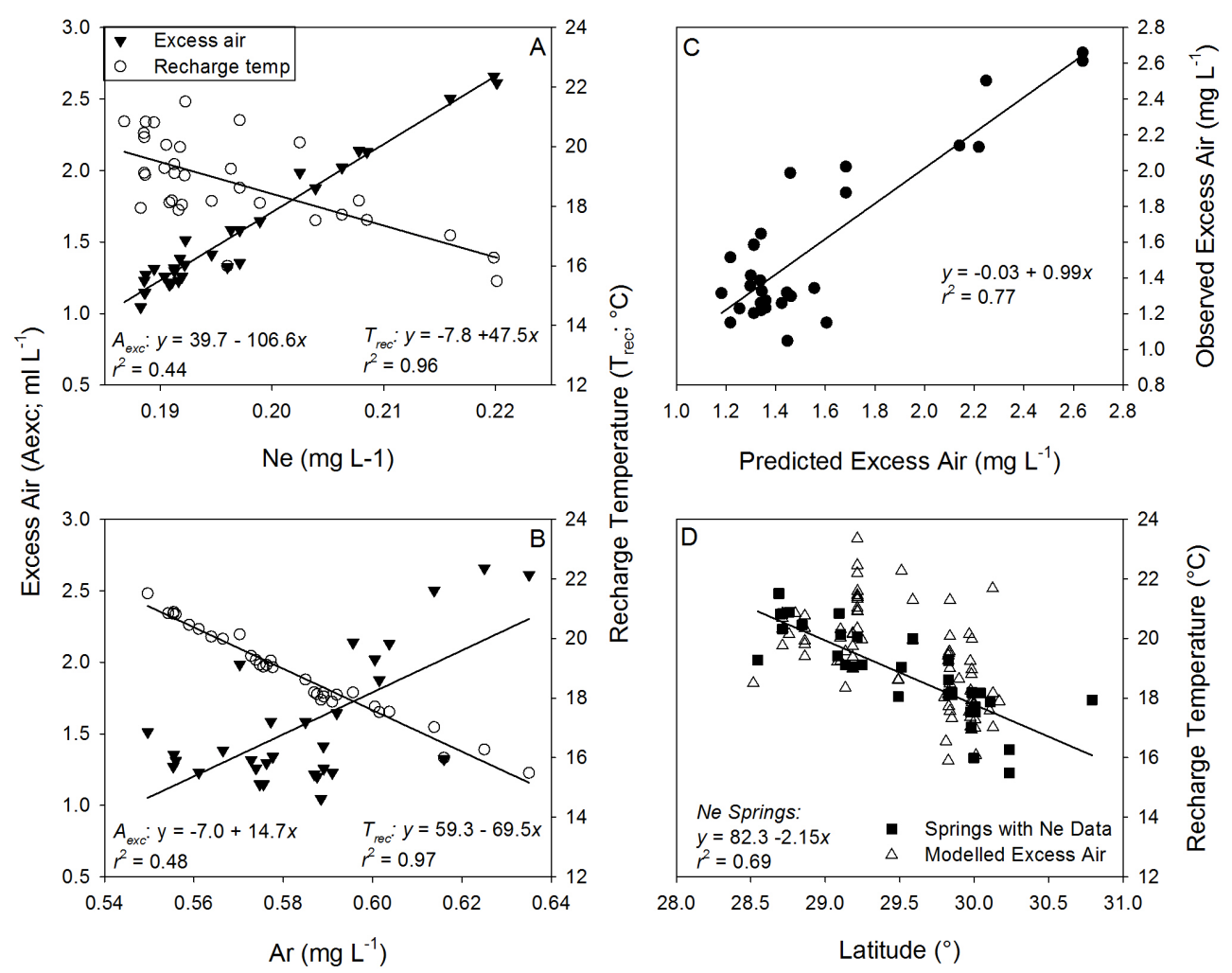

Fig. 2. Geochemical indicators $(\mathbf{A}, \mathbf{B})$ and springshed predictors $(\mathbf{C}, \mathbf{D})$ of excess air $\left(\mathrm{A}_{\mathrm{exc}}\right)$ and recharge temperature $\left(\mathrm{T}_{\text {rec }}\right)$ in Florida springs. (A) Ne concentrations are the overwhelming determinant of $A_{\text {exc }}$ estimates, and only weakly correlated with $\mathrm{T}_{\mathrm{rec}}$; (B) Ar concentrations had relatively small influence on $\mathrm{A}_{\text {exc }}$ estimates, but a high degree of influence over estimates of $\mathrm{T}_{\text {rec }}$. These relationships permit statistical determination of excess air and robust estimation of recharge temperature for springs without Ne measurements. (C) $A_{\text {exc }}$ across springs was best predicted by the combination of aquifer vulnerability $\left(\mathrm{V}_{\mathrm{aq}}\right)$ and spring size as measured by mean historic discharge ( $\left.\mathrm{Q}_{\text {por }}\right)$. (D) $\mathrm{T}_{\text {rec }}$ decreased with increasing latitude, a relationship that is clearer among springs for which $\mathrm{Ne}$ data allowed simultaneous direct estimation of A exc.

$\mathrm{NO}_{3}^{-}$(i.e. that assimilation, dissimilatory nitrate reduction to ammonium [DNRA], etc. are negligible) as indicated by concentrations of ammonium and particulate and dissolved organic nitrogen that are typically below detection limits at spring vents. Effects of these processes on $\delta^{15} \mathrm{~N}_{\mathrm{NO} 3}$ are also assumed to be zero.

Estimates of $\left[\mathrm{NO}_{3}^{-}\right]_{\text {init }}$ allow determination of the progression of denitrification. For each observation, we calculated the proportion of nitrate remaining from the original pool $\left(\mathrm{NO}_{3}^{-}\right)_{\mathrm{R}}$ as:

$\left[\mathrm{NO}_{3}^{-}\right]_{\mathrm{R}}=\frac{\left[\mathrm{NO}_{3}^{-}\right]_{\mathrm{obs}}}{\left[\mathrm{NO}_{3}^{-}\right]_{\text {init }}}$

where $\left[\mathrm{NO}_{3}^{-}\right]_{\text {obs }}$ is measured concentration, and $\left[\mathrm{NO}_{3}^{-}\right]_{\text {init }}$ is the initial concentration. We used linear regression to determine the isotopic enrichment factor $\left({ }^{15} \varepsilon\right)$ for $\delta^{15} \mathrm{~N}_{\mathrm{NO} 3}$ (assuming Rayleigh distillation kinetics) as the slope of the relationship between $\delta^{15} \mathrm{~N}_{\mathrm{NO} 3}$ and $\ln \left(\left[\mathrm{NO}_{3}^{-}\right]_{\mathrm{R}}\right.$ ) (Mariotti, 1986; Bohlke et al., 2002; Green et al., 2008). We excluded springs with $\mathrm{NO}_{3}^{-}$concentrations below $0.05 \mathrm{mg} \mathrm{L}^{-1}$ (Juniper, Silver
Glen, and Alexander Springs) from this analysis due to the high variability of $\left[\mathrm{N}_{2}\right]_{\text {den }}$ estimates relative to these lower concentrations.

For the Ichetucknee Springs time series, we calculated $\left[\mathrm{NO}_{3}^{-}\right]_{\mathrm{R}}$ for each spring and sampling date by assuming that $\left[\mathrm{NO}_{3}^{-}\right]_{\text {init }}$ for all springs was equal to $\left[\mathrm{NO}_{3}^{-}\right]_{\text {obs }}$ in the Ichetucknee Headspring on the same date. The first assumption implicit in this analysis is that denitrification rates in the Ichetucknee Headspring are negligible. High $\mathrm{O}_{2}$ concentrations (mean $\pm \mathrm{SD}: 4.1 \pm 0.2 \mathrm{mg} \mathrm{O}_{2} \mathrm{~L}^{-1}$ ), low values of $\left[\mathrm{N}_{2}\right]_{\text {den }}$ (which averaged $0.32 \mathrm{mg} \mathrm{N} \mathrm{L}^{-1}$ and represented minimal $(<30 \%)$ depletion of the estimated original nitrate pool), and the low and temporally stable $\delta^{15} \mathrm{~N}_{\mathrm{NO} 3}$ (mean \pm SD: $3.6 \pm 0.3, n=16$ ) observed in the Ichetucknee Headspring all support this assumption. The second implicit assumption, that springsheds of the Ichetucknee springs receive equivalent areal rates of $\mathrm{N}$ inputs from sources with identical isotopic signatures, is based on the relative homogeneity of land use in the Ichetucknee springshed, and the predominance of fertilizer application to improved pasture as a 

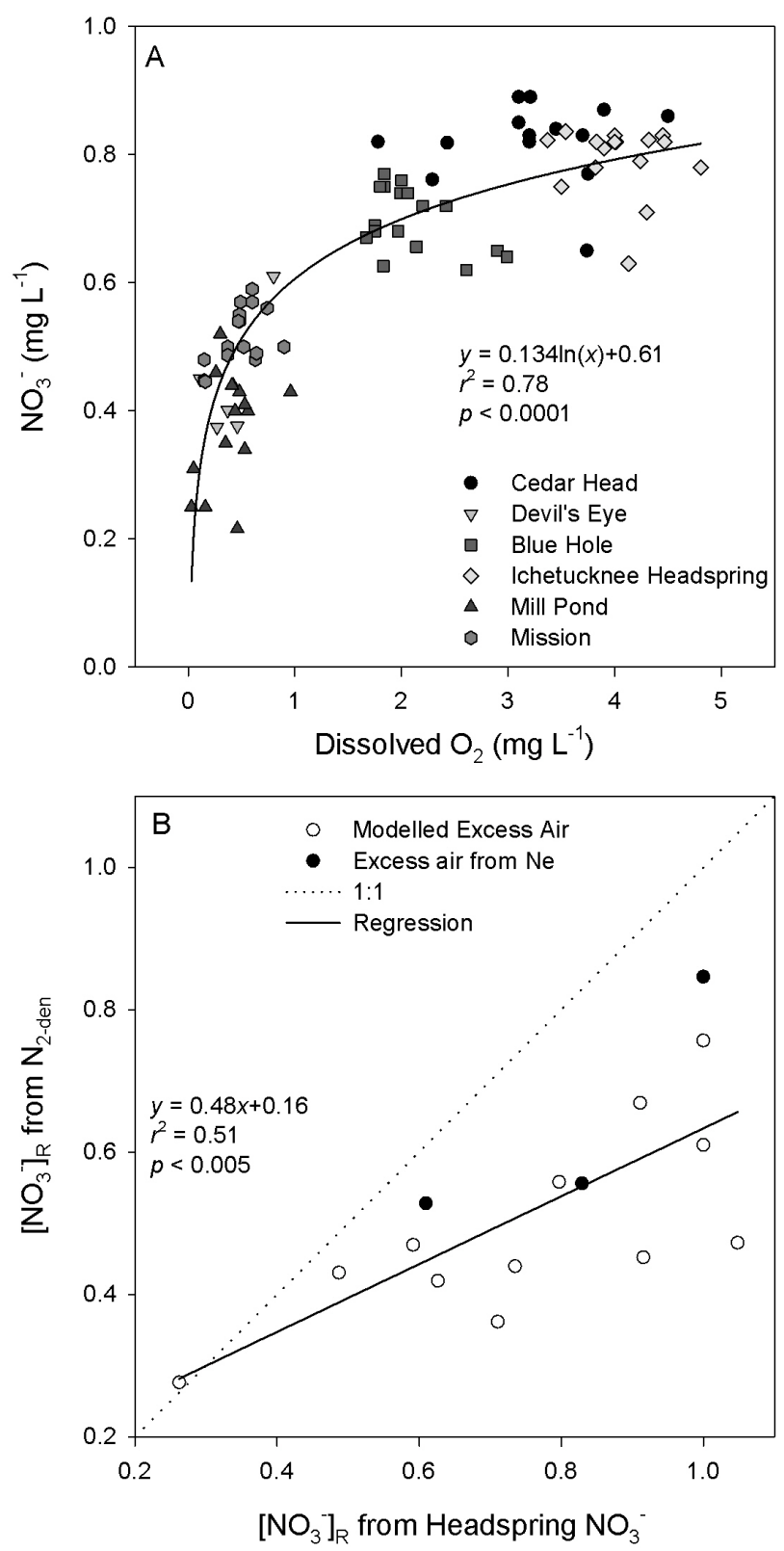

Fig. 3. Denitrification as a driver of nitrate concentration in the springs of the Ichetucknee River as indicated by (A) correlations between dissolved $\mathrm{O}_{2}$ and $\mathrm{NO}_{3}^{-}$and (B) correlations between estimates of residual nitrate pools $\left[\mathrm{NO}_{3}^{-}\right]_{\mathrm{R}}$ from differences between the Ichetucknee Headspring and from direct measures of denitrification-derived $\mathrm{N}_{2}\left(\left[\mathrm{~N}_{2}\right]_{\text {den }}\right)$.

source of $\mathrm{N}$ to the watershed (Katz et al., 2009). The third assumption, that variation among springs of the Ichetucknee is driven by denitrification, is supported by strong correlations between dissolved $\mathrm{O}_{2}$ and $\mathrm{NO}_{3}^{-}$within and across these systems (Fig. 3a).

To further evaluate the latter two assumptions, we used $\left[\mathrm{NO}_{3}^{-}\right]_{\text {init }}$ and $\left[\mathrm{NO}_{3}^{-}\right]_{\mathrm{R}}$ values for the springs of the
Ichetucknee River on three dates when $\left[\mathrm{N}_{2}\right]_{\text {den }}$ estimates were available. First, we compared $\left[\mathrm{NO}_{3}^{-}\right]_{\text {init }}$ from the Ichetucknee Headspring with the mean value of other springs on the same date. The similarity and covariation of these values (Table 2) is consistent with the assumption that all springs in the Ichetucknee System receive similar N loads. In addition, we assessed the correlation between alternative estimates of $\left[\mathrm{NO}_{3}^{-}\right]_{\mathrm{R}}$, namely estimates calculated from $\left[\mathrm{N}_{2}\right]_{\text {den }}$ and $\mathrm{NO}_{3}^{-}$from each spring and those estimated from the differences in $\mathrm{NO}_{3}^{-}$concentration between each spring and the Ichetucknee Headspring (Fig. 3a). The relationship between these estimates (Fig. 3b) suggests that the $\mathrm{NO}_{3}^{-}$ difference approach used in the analysis of the Ichetucknee Springs time series provides a more conservative estimate of the progression of denitrification than those determined using $\left[\mathrm{N}_{2}\right]_{\text {den }}$, which is to be expected if denitrification has also reduced $\mathrm{NO}_{3}^{-}$concentrations to a small degree in the Ichetucknee Headspring. More importantly, the correlation between these estimates is consistent with the assumption that variation in $\mathrm{NO}_{3}^{-}$concentration both within and among the springs of the Ichetucknee River is driven at least in part by differences in the progression of denitrification along the flowpaths that contribute to these springs.

We used fractionation factors $\left({ }^{15} \varepsilon\right)$ from our analyses, along with individual measures of denitrification progression $\left(\left[\mathrm{NO}_{3}\right]_{\mathrm{R}}\right)$ to estimate the original isotopic composition of source $\mathrm{N}$ for each observation, according to:

$\delta^{15} \mathrm{~N}_{\text {source }}=\delta^{15} \mathrm{~N}_{\text {observed }}+\ln \left[\mathrm{NO}_{3}\right]_{\mathrm{R}} \times{ }^{15} \varepsilon$

This calculation assumes that fractionation is constant in space and time within the UFA, and ignores potential mixing effects (Green et al., 2010). To assess the effects of denitrification at the regional scale, we compared the distributions of observed $\delta^{15} \mathrm{~N}$ and estimated $\delta^{15} \mathrm{~N}_{\text {source }}$, using the reference values reported by Heaton (1986), whose distinguish synthetic fertilizer, organic waste, and their mixtures as $<6 \%$ o for synthetic sources, $>9 \%$ for animal-derived sources, and intermediate values for mixtures. Despite the potential for isotopic composition of these sources to vary in space of and time (Kendall 1998), the reliance on these values by policy makers in Florida makes them important benchmarks.

\section{Results}

For the vast majority of our observations, $\mathrm{N}_{2}$ concentrations exceeded values predicted from recharge temperature and excess air (51 of 61 springs; 94 of 112 observations). $\left[\mathrm{N}_{2}\right]_{\text {den }}$ ranged from -0.7 to $3.5 \mathrm{mg} \mathrm{N}_{2} \mathrm{~L}^{-1}$ (median: $0.67 \mathrm{mg} \mathrm{N}_{2} \mathrm{~L}^{-1}$; mean \pm SD: $0.82 \pm 0.83 \mathrm{mg} \mathrm{N}_{2} \mathrm{~L}^{-1}$ ), and was inversely correlated with $\mathrm{O}_{2}$ (Fig. 4a). Among springs with $\mathrm{Ne}$ data, this relationship exhibited a sharp break at ca. $2 \mathrm{mg} \mathrm{O}_{2} \mathrm{~L}^{-1}$, above which $\left[\mathrm{N}_{2}\right]_{\mathrm{den}}$ averaged $0.003 \mathrm{mg} \mathrm{N}_{2} \mathrm{~L}^{-1}$ ( $\pm 0.32 ; 2 \mathrm{SE}$ ); below $2 \mathrm{mg} \mathrm{O}_{2} \mathrm{~L}^{-1}$, $\left[\mathrm{N}_{2}\right]_{\text {den }}$ averaged $1.5 \mathrm{mg} \mathrm{N}_{2} \mathrm{~L}^{-1}( \pm 0.33 ; 2 \mathrm{SE})$. Among all 
Table 2. Alternative estimates of initial $\mathrm{NO}_{3}^{-}$concentration $\left(\left[\mathrm{NO}_{3}^{-}\right]_{\text {init }}\right)$ and the proportion of $\left[\mathrm{NO}_{3}^{-}\right]_{R}$ remaining in springs of the Ichetucknee River for dates when direct estimates of denitrification $\left(\left[\mathrm{N}_{2}\right]_{d e n}\right)$ are available. All values are in $\mathrm{mg} \mathrm{N} \mathrm{L}^{-1}$.

\begin{tabular}{|c|c|c|c|c|c|c|c|}
\hline Date & Spring & $\mathrm{NO}_{3}^{-}$ & {$\left[\mathrm{N}_{2}\right]_{\mathrm{den}}$} & {$\left[\mathrm{NO}_{3}^{-}\right]_{\mathrm{R}-\mathrm{NO} 3}^{\mathrm{a}}$} & {$\left[\mathrm{NO}_{3}^{-}\right]_{\mathrm{R}-\mathrm{N} 2 \mathrm{den}}^{\mathrm{b}}$} & {$\left[\mathrm{NO}_{3}^{-}\right]_{\text {init }}^{\mathrm{c}}$} & Mean $\left[\mathrm{NO}_{3}^{-}\right]_{\text {init }}(\mathrm{SD})^{\mathrm{d}}$ \\
\hline \multirow[t]{3}{*}{$10 / 24 / 01$} & Blue Hole & 0.68 & 0.54 & 0.83 & 0.56 & 1.22 & \\
\hline & Mission & 0.50 & 0.45 & 0.61 & 0.53 & 0.95 & \\
\hline & Headspring & 0.82 & 0.15 & 1.00 & 0.85 & 0.97 & $1.09(0.2)$ \\
\hline \multirow[t]{5}{*}{$1 / 30 / 07$} & Devil's Eye & 0.61 & 0.78 & 0.73 & 0.44 & 1.39 & \\
\hline & Blue Hole & 0.76 & 0.92 & 0.92 & 0.45 & 1.68 & \\
\hline & Mill Pond & 0.52 & 0.72 & 0.63 & 0.42 & 1.24 & \\
\hline & Mission & 0.59 & 1.04 & 0.71 & 0.36 & 1.63 & \\
\hline & Headspring & 0.83 & 0.53 & 1.00 & 0.61 & 1.36 & $1.49(0.21)$ \\
\hline \multirow[t]{5}{*}{$6 / 9 / 10$} & Devil's Eye & 0.40 & 0.53 & 0.49 & 0.43 & 0.93 & \\
\hline & Blue Hole & 0.66 & 0.52 & 0.80 & 0.56 & 1.18 & \\
\hline & Mill Pond & 0.22 & 0.57 & 0.26 & 0.28 & 0.78 & \\
\hline & Mission & 0.49 & 0.55 & 0.59 & 0.47 & 1.04 & \\
\hline & Headspring & 0.82 & 0.26 & 1.00 & 0.76 & 1.09 & $0.98(0.17)$ \\
\hline
\end{tabular}

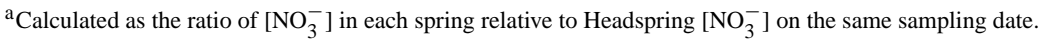

${ }^{\mathrm{b}}$ Calculated as the ratio of $\left[\mathrm{NO}_{3}^{-}\right]$in each spring relative to $\left[\mathrm{NO}_{3}^{-}\right]_{\text {init }}$ for that spring on the same sampling date.

${ }^{c}$ Calculated as the sum of $\left[\mathrm{NO}_{3}^{-}\right]$and $\left[\mathrm{N}_{2}\right]_{\text {den }}$ for each sampling date.

${ }^{\mathrm{d}}$ Calculated from all springs other than the Ichtetucknee Headspring for which data are available on each date.

Table 3. Results of analysis of variance (ANOVA) to evaluate within- vs. among-spring variation in the concentration of denitrification-derived $\mathrm{N}_{2}\left(\left[\mathrm{~N}_{2}\right]_{\text {den }}\right)$, proportional size of residual nitrate pool $\left(\left[\mathrm{NO}_{3}^{-}\right]_{\mathrm{R}}\right)$, and isotopic signature of nitrate $\left(\delta^{15} \mathrm{~N}_{\mathrm{NO} 3}\right)$.

\begin{tabular}{llllll}
\hline Source & SSE & df & MSE & $\boldsymbol{F}$ & $\boldsymbol{p}$ \\
\hline$N_{2-\text { den }}$ & & & & & \\
Spring & 44.744 & 15 & 2.983 & 23.367 & $<0.0001$ \\
Error & 4.723 & 37 & .128 & & \\
{$\left[N O_{3}^{-}\right]_{\mathrm{R}}$} & & & & & \\
Spring & 38634.0 & 15 & 2575.6 & 15.842 & $<0.0001$ \\
Error & 5202.6 & 32 & 162.6 & & \\
$\delta^{15} N_{\mathrm{NO} 3}$ & & & & & \\
Spring & 2699.296 & 33 & 81.797 & 3.039 & $<0.0001$ \\
Error & 434.824 & 165 & 2.635 & & \\
\hline
\end{tabular}

springs, this threshold was less distinct, and a linear relationship was a better fit than a logarithmic relationship.

Among the 16 springs with 3 or more observations $(\max =5)$ of $\left[\mathrm{N}_{2}\right]_{\mathrm{den}}$, over $90 \%$ of the total variation in $\left[\mathrm{N}_{2}\right]_{\text {den }}$ occurred among rather than within springs (ANOVA; Fig. 5a, Table 3). Standard deviations within springs for $\left[\mathrm{N}_{2}\right]_{\text {den }}$ ranged from 0.05 to $0.65 \mathrm{mg} \mathrm{N}_{2} \mathrm{~L}^{-1}$ and averaged $0.31 \mathrm{mg} \mathrm{L}^{-1}$. Among the same set of springs, over $88 \%$ of total variation in $\left[\mathrm{NO}_{3}^{-}\right]_{\mathrm{R}}$ occurred among springs (ANOVA; Fig. 5b, Table 3). Standard deviations within springs for $\left[\mathrm{NO}_{3}^{-}\right]_{\mathrm{R}}$ ranged from $<1 \%$ to $29 \%$ and averaged $10.4 \%$. For both variables, variation among springs was strongly correlated with mean dissolved $\mathrm{O}_{2}$ from the same set of observations. However, variation in $\left[\mathrm{N}_{2}\right]_{\mathrm{den}}$ and $\left[\mathrm{NO}_{3}^{-}\right]_{\mathrm{R}}$ within springs was not correlated with variation within springs in dissolved $\mathrm{O}_{2}$, presumably due to low sample size

Fluxes of $\left[\mathrm{N}_{2}\right]_{\text {den }}$ from UFA springs were comparable to but uncorrelated with those of $\mathrm{NO}_{3}^{-}$, and the proportion of $\mathrm{NO}_{3}^{-}$removed by denitrification varied among springs from 0 to as high as $97 \%$ (mean \pm 2 SE: $34 \pm 9 \%$ ) among springs. Denitrification removed more than $75 \%$ of $\mathrm{N}$ inputs in 8 of 61 springs, and more than $50 \%$ in 20 of 61 . Compared to this spatial heterogeneity, temporal variation in $\left[\mathrm{N}_{2}\right]_{\text {den }}$ among springs was low (Fig. 5, Table 3). We estimate that denitrification reduced total flow-weighted $\mathrm{NO}_{3}^{-}$ flux from sampled UFA springs by $32 \%$, with uncertainty in this estimate primarily driven by the representativeness of our sample of springs. Volumetric denitrification rates calculated from $\left[\mathrm{N}_{2}\right]_{\text {den }}$ and ${ }^{3} \mathrm{H} /{ }^{3} \mathrm{He}$ water age (Green et al., 2008) averaged $5.13 \mu \mathrm{mol} \mathrm{m}{ }^{-3} \mathrm{~d}^{-1}$, with a maximum rate of $24.1 \mu \mathrm{mol} \mathrm{m}^{-3} \mathrm{~d}^{-1}$. Aggregate (i.e. flow-weighted) areal denitrification for all springsheds was $1.22 \mathrm{~kg} \mathrm{ha}^{-1} \mathrm{yr}^{-1}$, with ca. $20 \%$ of springsheds exceeding the estimated global average for groundwater denitrification $\left(3.49 \mathrm{~kg} \mathrm{ha}^{-1} \mathrm{yr}^{-1}\right.$; Seitzinger et al. 2006).

Across 292 observations from 103 springs, $\delta^{15} \mathrm{~N}_{\mathrm{NO} 3}$ ranged from -0.3 to $23.9 \%$, was inversely correlated with $\mathrm{O}_{2}$, and varied more among low- $\mathrm{O}_{2}\left(<2 \mathrm{mg} \mathrm{L}^{-1}\right)$ than high$\mathrm{O}_{2}$ springs (Fig. 4b). Among springs with 3 or more observations $(\max =18)$ of $\delta^{15} \mathrm{~N}_{\mathrm{NO} 3}, 86 \%$ of the total variation in $\delta^{15} \mathrm{~N}_{\mathrm{NO} 3}$ in our data set was accounted for by variation among springs (ANOVA; Fig. 6, Table 3). Standard deviations of $\delta^{15} \mathrm{~N}_{\mathrm{NO} 3}$ within individual springs ranged from 0.1 to $5.2 \%$ and averaged $1.4 \%$. Unlike $\left[\mathrm{N}_{2}\right]_{\text {den }}$ and $\left[\mathrm{NO}_{3}^{-}\right]_{\mathrm{R}}$, variation within springs in $\delta^{15} \mathrm{~N}_{\mathrm{NO} 3}$ was also correlated with variation in dissolved $\mathrm{O}_{2}$, particularly for low $\mathrm{O}_{2}$ springs, 


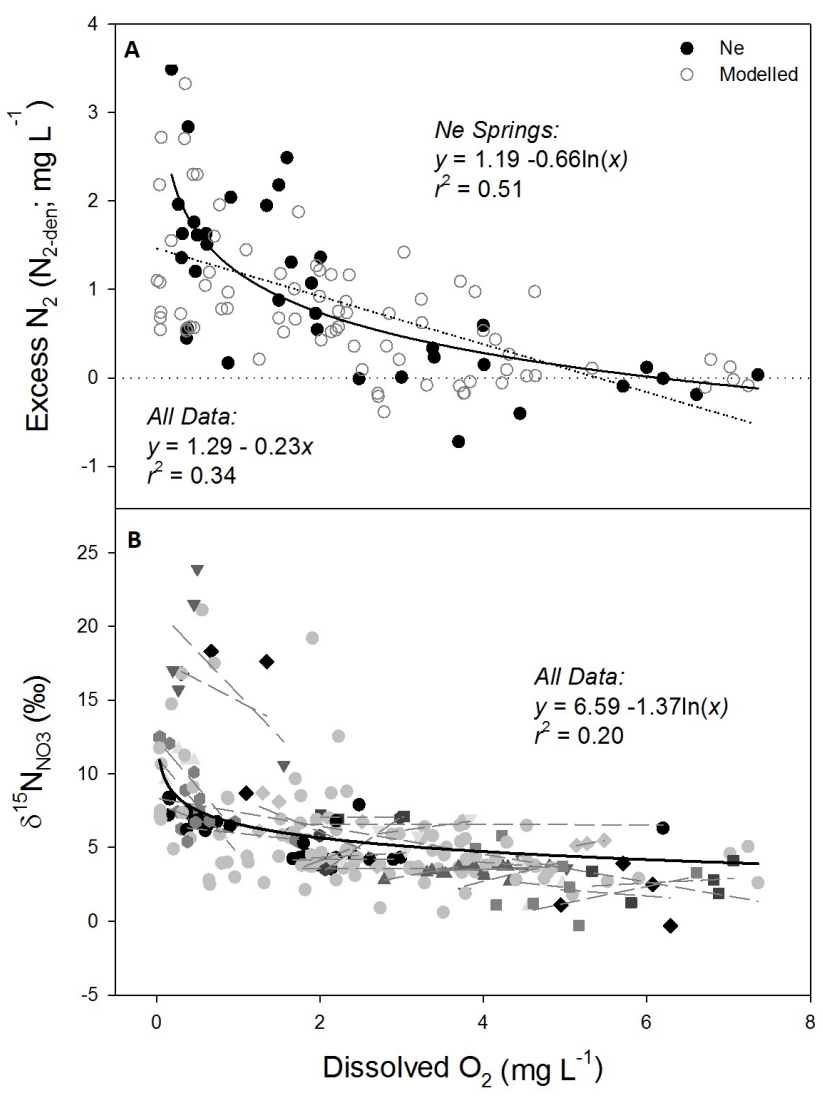

Fig. 4. Dissolved oxygen as a predictor of (A) excess $\mathrm{N}_{2}$ and (B) $\delta^{15} \mathrm{~N}_{\mathrm{NO} 3}$ in Florida springs. In (A), closed symbols indicate measurements of denitrification-derived $\mathrm{N}_{2}\left(\left[\mathrm{~N}_{2}\right]_{\mathrm{den}}\right)$ based on direct estimation of excess air and recharge temperature via $\mathrm{Ne}$ and $\mathrm{Ar}$; best fit for Ne springs is given by the solid line. Open symbols in (A) indicate $\left[\mathrm{N}_{2}\right]_{\text {den }}$ measurements based on modeled excess air and estimation of recharge temperature from Ar; best fit for all $\left[\mathrm{N}_{2}\right]_{\text {den }}$ data are shown by the dashed line. In (B), open symbols indicate data from springs with 3 or fewer observations; closed symbols indicate data from springs with 4 or more observations. Lines in (B) are best-fit linear regressions for individual springs with four or more observations of $\mathrm{O}_{2}$ and $\delta^{15} \mathrm{~N}_{\mathrm{NO} 3}$. Springs with high $\mathrm{O}_{2}$ exhibit little variation in $\delta^{15} \mathrm{~N}_{\mathrm{NO}}$, but low $\mathrm{O}_{2}$ springs exhibit higher variability in $\delta^{15} \mathrm{~N}_{\mathrm{NO} 3}$ that is linked to variation in oxygen concentrations. Best-fit parameters for individual springs and their relationship to mean dissolved $\mathrm{O}_{2}$ is shown in Fig. 7.

which had strong, steeply negative relationships between temporal variation in $\delta^{15} \mathrm{~N}_{\mathrm{NO} 3}$ and dissolved $\mathrm{O}_{2}$ (Fig. 7).

The progression of denitrification, as indicated by $\left[\mathrm{NO}_{3}^{-}\right]_{\mathrm{R}}$, was a strong predictor of $\delta^{15} \mathrm{~N}_{\mathrm{NO} 3}$ in both the synoptic survey and Ichetucknee River time series (Fig. 8a, b). Estimated fractionation coefficients $\left({ }^{15} \varepsilon\right)$ were similar between the Ichetucknee River time series (7.37) and the synoptic survey (7.49), though slightly less so when springs without $\mathrm{Ne}$ data were considered (5.27). Both data sets also exhibited strong relationships between nitrate $\delta^{15} \mathrm{~N}_{\mathrm{NO} 3}$ and $\delta^{18} \mathrm{O}_{\mathrm{NO} 3}$; however, the slope of

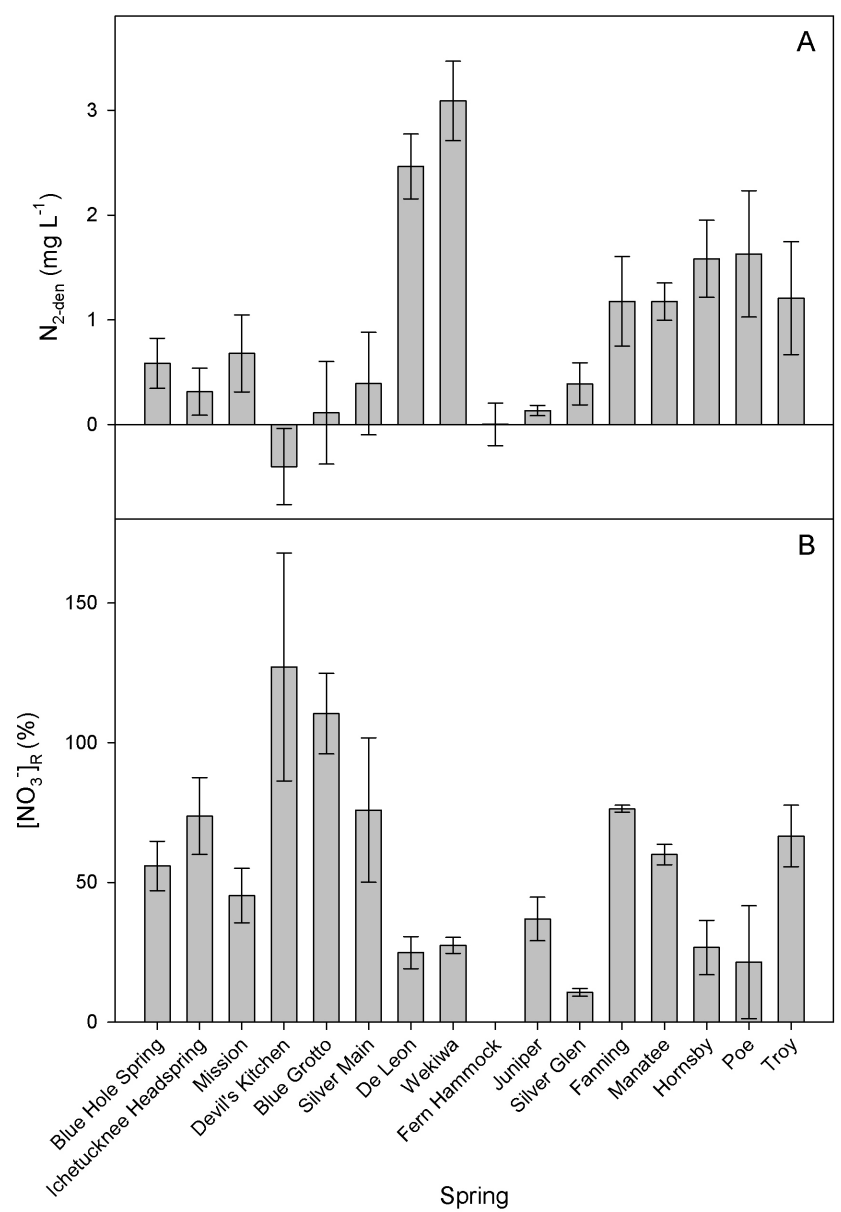

Fig. 5. Variation in the magnitude of denitrification $\left[\mathrm{N}_{2}\right]_{\mathrm{den}}$; panel (A) and residual nitrate pools $\left[\mathrm{NO}_{3}^{-}\right]_{\mathrm{R}}$; panel (B) within and among springs of the Upper Floridan Aquifer. Variation among springs accounts for more than $90 \%$ of total variation in $\left[\mathrm{N}_{2}\right]_{\text {den }}$. Full results of analysis of variance are given in Table 3. Data shown are from all springs with 3 or more estimates of $\left[\mathrm{N}_{2}\right]_{\text {den }}$.

this relationship differed substantially between the synoptic cross-system survey (1.8:1) and the Ichetucknee River time series $(1: 1$; Fig. $8 \mathrm{c}$, d). For the Ichetucknee River springs, relationships between $\delta^{15} \mathrm{~N}_{\mathrm{NO} 3}$ and $\delta^{18} \mathrm{O}_{\mathrm{NO} 3}$ within sampling dates were consistently near unity (Table 4 ).

Estimates of source $\delta^{15} \mathrm{~N}_{\mathrm{NO} 3}$ from denitrification progression and observed $\delta^{15} \mathrm{~N}_{\mathrm{NO}}$ values suggest that denitrification alters $\delta^{15} \mathrm{~N}_{\mathrm{NO} 3}$ at the regional scale. Among springs with estimates of $\left[\mathrm{N}_{2}\right]_{\text {den }}$, nearly $20 \%$ of observed $\delta^{15} \mathrm{~N}_{\mathrm{NO} 3}$ values were greater than $9 \%$, and more than $50 \%$ were greater than $6 \% 0$ (Fig. 9c), values used in Florida and elsewhere to delineate inorganic and organic sources and mixtures thereof (Katz, 2004; Bohlke, 2002). Estimated $\delta^{15} \mathrm{~N}_{\mathrm{NO} 3}$ of source $\mathrm{N}$ (Fig. 9d) were much lower, with only $3.3 \%$ of observations estimated to have original source $\delta^{15} \mathrm{~N}_{\mathrm{NO} 3}$ greater than $9 \%$, and $31 \%$ greater than $6 \%$. Within the Ichetucknee River time series, differences between the distribution of observed 


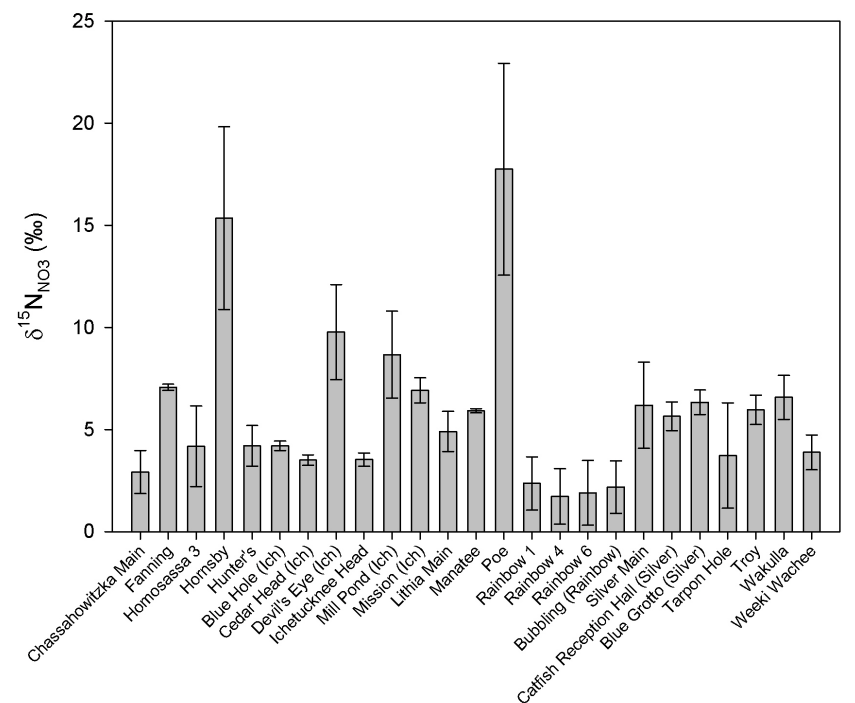

Fig. 6. Variation in nitrate isotopic composition $\left(\delta^{15} \mathrm{~N}_{\mathrm{NO}}\right)$ within and among springs of the Upper Floridan Aquifer. Variation among springs accounts for more than $90 \%$ of total variation in $\delta^{15} \mathrm{~N}_{\mathrm{NO} 3}$. Full results of analysis of variance are given in Table 3. Data shown are from all springs with 3 or more measurements of $\delta^{15} \mathrm{~N}_{\mathrm{NO} 3}$.

Table 4. Intercept $\left(\beta_{0}\right)$, slope $\left(\beta_{1}\right)$, and covariation strength $\left(r^{2}\right)$ of $\delta^{15} \mathrm{~N}_{\mathrm{NO} 3}-\delta^{18} \mathrm{O}_{\mathrm{NO} 3}$ relationships on individual dates from the Ichetucknee River springs time series.

\begin{tabular}{llll}
\hline Date & $\beta_{0}$ & $\beta_{1}$ & $r^{2}$ \\
\hline 30 Jan 2007 & 0.91 & 1.13 & 0.982 \\
3 Jul 2007 & 6.64 & 0.95 & 0.942 \\
2 Aug 2007 & 7.93 & 0.72 & 0.997 \\
14 Sept 2007 & 4.95 & 1.20 & 0.979 \\
18 Oct 2007 & 5.03 & 1.15 & 0.983 \\
29 Nov 2007 & 5.70 & 1.02 & 0.964 \\
18 Dec 2007 & 5.32 & 1.09 & 0.994 \\
17 Jan 2008 & 6.39 & 0.91 & 0.961 \\
22 Feb 2008 & 5.54 & 1.04 & 0.979 \\
27 Mar 2008 & 5.03 & 1.12 & 0.960 \\
24 Apr 2008 & 5.21 & 1.09 & 0.992 \\
26 Jun 2008 & 4.97 & 1.15 & 0.975 \\
15 Mar 2009 & 2.98 & 0.91 & 0.988 \\
14 Oct 2009 & 1.52 & 1.25 & 0.994 \\
16 Nov 2009 & 0.33 & 1.34 & 0.985 \\
9 Jun 2010 & 3.95 & 1.05 & 0.999 \\
\hline Mean & 4.52 & 1.07 & 0.980 \\
SD & 1.84 & 0.14 & 0.007 \\
Min & 0.33 & 0.72 & 0.942 \\
Max & 7.93 & 1.34 & 0.999 \\
\hline
\end{tabular}

and estimated source $\delta^{15} \mathrm{~N}_{\mathrm{NO}}$ were even greater (Fig. 9e, f). Across all observations of $\delta^{15} \mathrm{~N}_{\mathrm{NO} 3}$, values greater than $6 \%$ o were common $(>33 \%)$, but were rare among springs with DO greater than $3 \mathrm{mg} \mathrm{L}^{-1}$ (Fig. 9a, b). In all three data sets,

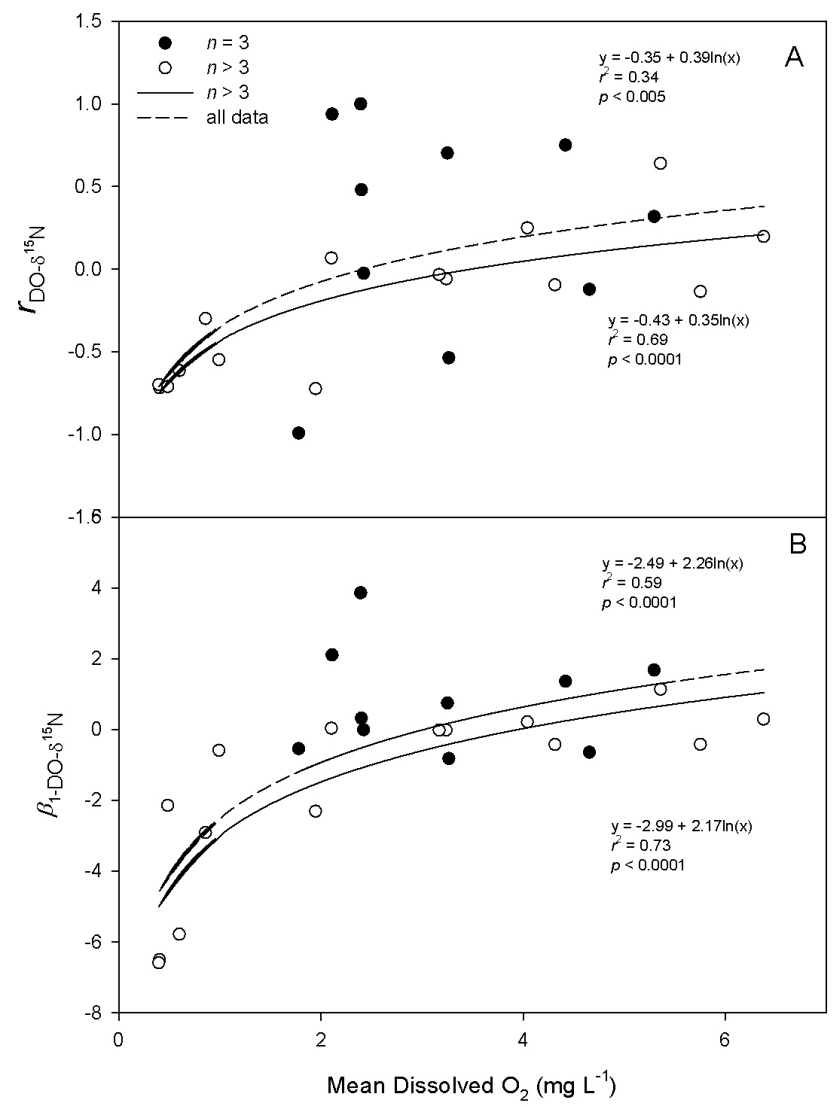

Fig. 7. Parameters of within-spring relationships between dissolved $\mathrm{O}_{2}$ and $\delta^{15} \mathrm{~N}_{\mathrm{NO} 3}$ as a function of spring mean dissolved oxygen. Large negative values of both (A) correlation coefficient and (B) slope in low- $\mathrm{O}_{2}$ springs, and their absence in higher- $\mathrm{O}_{2}$ systems, suggest that isotopically-enriched nitrate pools are associated with old, deeply anoxic flowpaths where denitrification would be most likely to occur. Open symbols indicate springs with 3 observations of $\mathrm{O}_{2}$ and $\delta^{15} \mathrm{~N}_{\mathrm{NO} 3}$. Closed symbols indicated springs with 4 or more observations.

estimated source $\delta^{15} \mathrm{~N}_{\mathrm{NO} 3}$ was both lower on average and much less variable than spring water.

\section{Discussion}

\subsection{Evidence for denitrification in the Upper Floridan Aquifer}

Relationships among denitrification-derived $\mathrm{N}_{2}\left(\left[\mathrm{~N}_{2}\right]_{\text {den }}\right)$, $\mathrm{O}_{2}$, and $\delta^{15} \mathrm{~N}_{\mathrm{NO} 3}$ and $\delta^{18} \mathrm{O}_{\mathrm{NO} 3}$ all support the widespread occurrence and significance of denitrification in the Upper Floridan Aquifer. In springs with low dissolved $\mathrm{O}_{2}, \mathrm{~N}_{2}$ concentrations exceeded those predicted by physical processes (as measured by noble gas tracers), but closely matched those predictions in high $\mathrm{O}_{2}$ springs (Fig. 4a). The negative relationship between $\mathrm{O}_{2}$ concentrations and $\left[\mathrm{N}_{2}\right]_{\text {den }}$ provides clear evidence of both the accuracy $\left(0.003 \mathrm{mg} \mathrm{N}_{2} \mathrm{~L}^{-1}\right)$ 

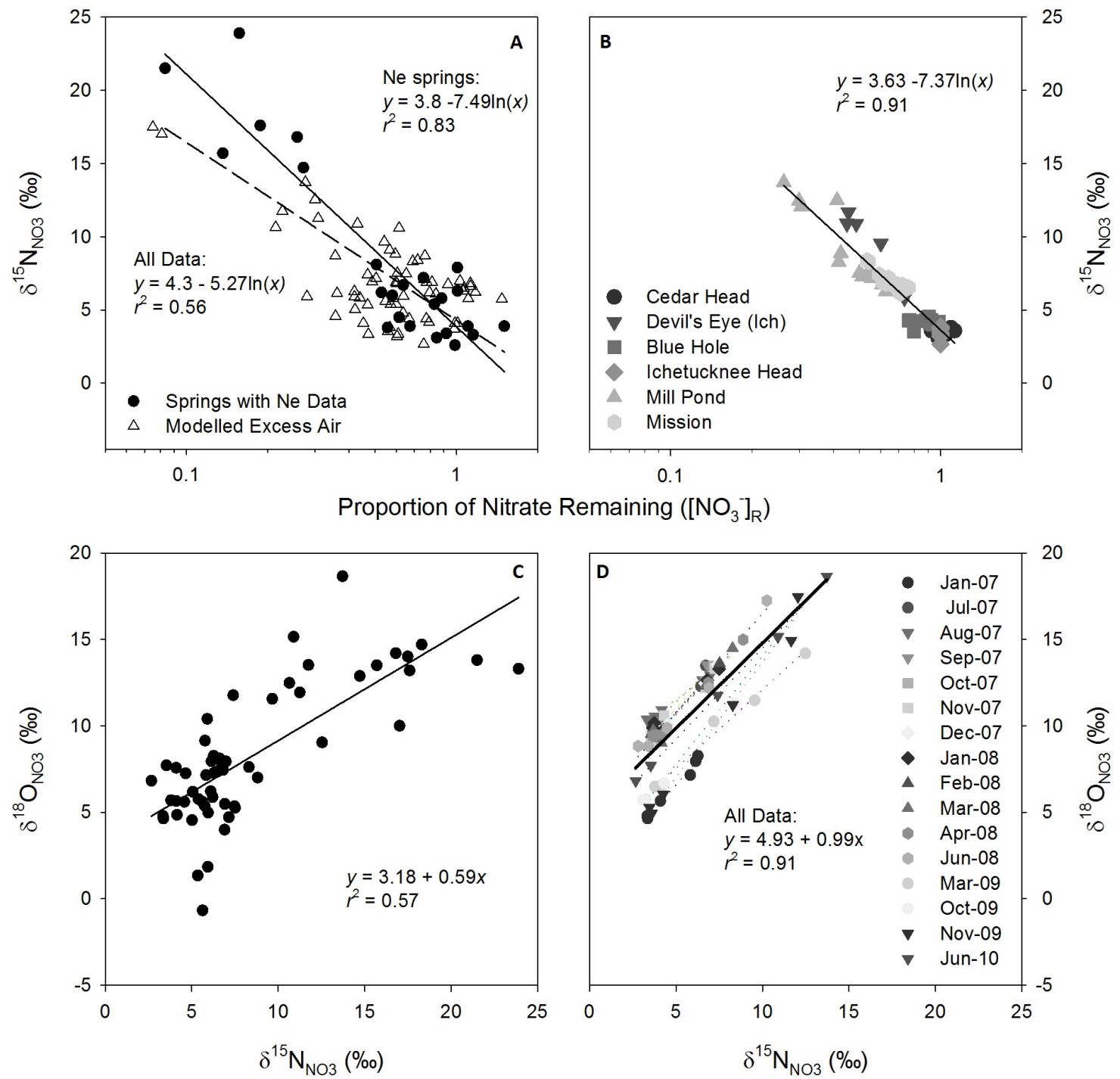

Fig. 8. Effects of denitrification on isotopic composition of nitrate in Florida springs. Variation in $\delta^{15} \mathrm{~N}_{\mathrm{NO}}$ was strongly correlated with denitrification progression (A) as estimated from excess $\mathrm{N}_{2}$ and observed nitrate concentrations across 61 springs, and (B) as estimated from differences between the Ichetucknee Headsprings and other springs in the Ichetucknee River. Positive correlation between $\delta^{15} \mathrm{~N}_{\mathrm{NO} 3}$ and $\delta^{18} \mathrm{O}_{\mathrm{NO} 3}(\mathbf{C})$ across springs and (D) over time within the Ichetucknee system are also consistent with denitrification rather than variation in source as a driver of $\delta^{15} \mathrm{~N}_{\mathrm{NO} 3}$.

and precision $\left( \pm 0.32 \mathrm{mg} \mathrm{N}_{2} \mathrm{~L}^{-1} ; 2 \mathrm{SE}\right)$ of our approach and the occurrence of denitrification in hypoxic portions of the UFA. Like $\left[\mathrm{N}_{2}\right]_{\mathrm{den}}, \delta^{15} \mathrm{~N}_{\mathrm{NO}}$ was inversely related to dissolved $\mathrm{O}_{2}$, with high values observed almost exclusively below $2 \mathrm{mg} \mathrm{O}_{2} \mathrm{~L}^{-1}$. $\delta^{15} \mathrm{~N}_{\mathrm{NO} 3}$ values for springs with $\mathrm{O}_{2}$ greater than $3 \mathrm{mg} \mathrm{L}^{-1}$ were generally consistent with nitrogen derived from predominantly but not exclusively inorganic sources (Figs. 4b, 9b).

Relationships between the progression of denitrification and $\delta^{15} \mathrm{~N}_{\mathrm{NO} 3}$ (Fig. 8a, b) support both the inference of denitrification in the UFA and the hypothesis that variation in isotopic signatures is primarily driven by denitrification rather than differential contribution from organic and inorganic sources. Fractionation coefficients $\left({ }^{15} \varepsilon\right)$ derived from both the cross-spring analysis and (5.27-7.49) the Ichetucknee River springs time series (7.37) are within the lower range of values reported for other aquifers (Mariotti, 1986; Bohlke et al., 2002; Green et al., 2008), and other marine and freshwater environments (Sigman et al., 2005; Granger et al., 2008), but are lower than some recent experimental values (Knoller et al., 2011). These relatively low values may indicate diffusion-constrained $\mathrm{NO}_{3}^{-}$limitation of denitrification 


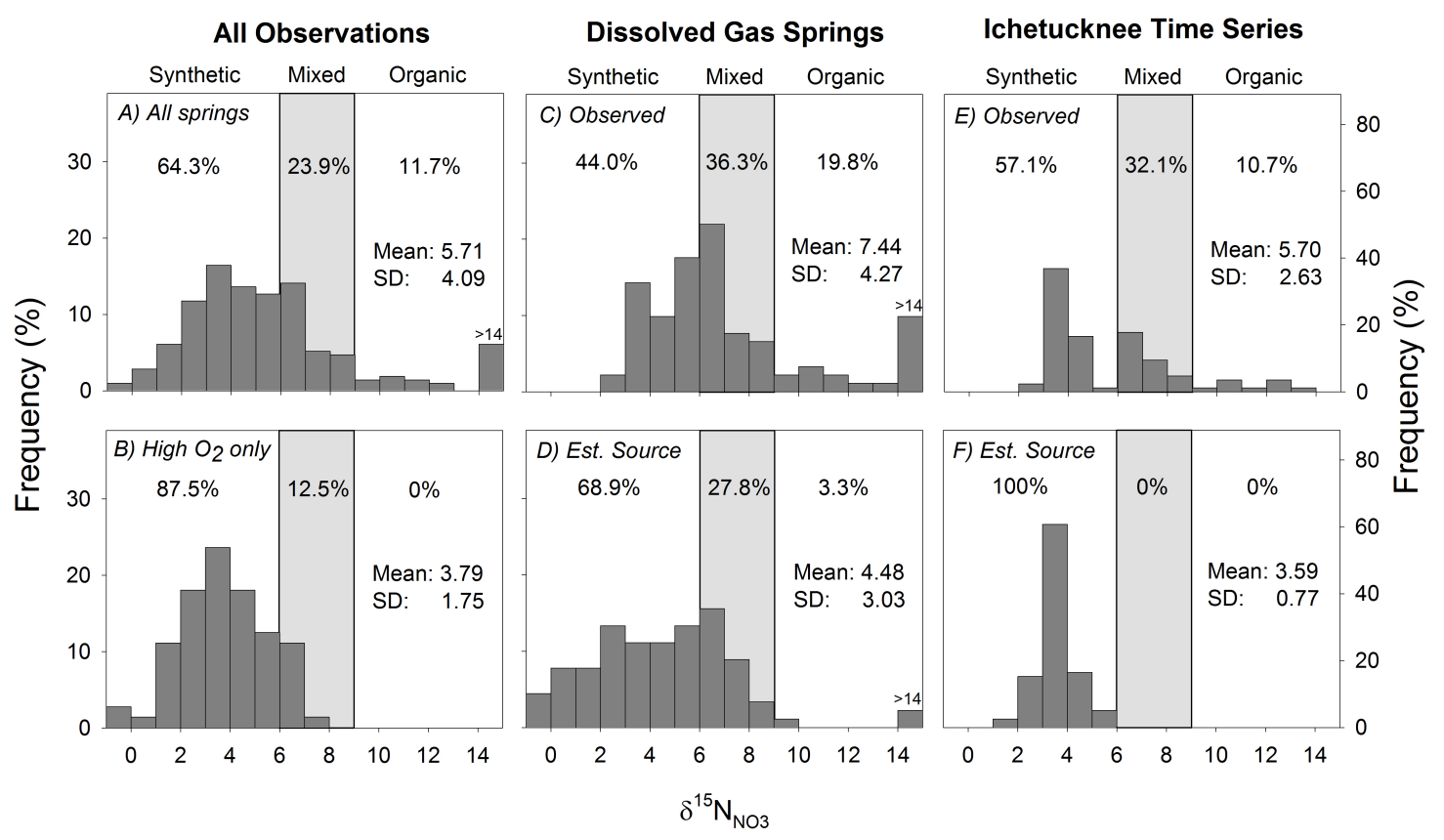

Fig. 9. Implications of fractionation by denitrification for inference of $\mathrm{N}$ sources to Florida springs. The distribution of $\delta^{15} \mathrm{~N}_{\mathrm{NO}} 3$ across all observations (A), among springs sampled for dissolved gases in this study (C) and from the Ichetucknee time series (E) all suggest meaningful contributions of organic sources (one third to one half of springs). However, $\delta^{15} \mathrm{~N}_{\mathrm{NO}}$ values in high DO springs (B) and source $\delta^{15} \mathrm{~N}_{\mathrm{NO} 3}$ as back-calculated from isotopic enrichment factor and denitrification progression (D, F) suggest inorganic fertilizers and soil $\mathrm{N}$ (from mineralized $\mathrm{OM}$ ) as the predominant source in the overwhelming majority of springs.

in the UFA (Sebilo et al., 2003), but could also be an artefact of mixing between distinct water sources (Green et al., 2010).

Covariation between $\delta^{15} \mathrm{~N}_{\mathrm{NO} 3}$ and $\delta^{18} \mathrm{O}_{\mathrm{NO} 3}$ confirms the inference of denitrification in the UFA and its influence on isotopic composition of $\mathrm{NO}_{3}^{-}$at the regional scale. Across springs and over time within the springs of the Ichetucknee River, we observed strong relationships between $\delta^{15} \mathrm{~N}_{\mathrm{NO}}$ and $\delta^{18} \mathrm{O}_{N O 3}$, although the slopes of these relationships differed between the synoptic survey and the temporally intensive study of the Ichetucknee system. The 1:1.7 relationship across sites (Fig. 8c) is consistent with theoretical and empirical studies showing 1:2 enrichment by denitrification (Lehmann et al., 2003; Aravena and Robertson, 1998). In contrast, covariation within the springs of the Ichetucknee River exhibited slopes near 1:1 on each date and across all dates (Fig. 8d, Table 4). A recent study of isotope dynamics within the Ichetucknee River itself yielded similar 1:1 fractionation ratio for ${ }^{18} \mathrm{O}:{ }^{15} \mathrm{~N}$ associated with denitrification (Cohen et al., 2012). These relationships, both from studies with independently-constrained, direct estimates of denitrification, are similar to fractionation ratios obtained from laboratory experiments (Granger et al., 2008) and marine systems (Sigman et al., 2005). The divergence of fractionation during denitrification between freshwater and marine ecosystems has been attributed to taxonomic or environmental differences between these systems, but our observations suggest factors varying among watersheds can alter these relationships. Regardless of these differences, strong covariation among $\delta^{15} \mathrm{~N}_{\mathrm{NO} 3}$ and $\delta^{18} \mathrm{O}_{\mathrm{NO} 3}$ provide additional evidence that denitrification drives variation in nitrate isotopic composition in the Floridan Aquifer.

Temporal patterns within individual springs provide a final line of support for denitrification as a driver of $\mathrm{NO}_{3}^{-}$ concentrations and isotopic composition. Within the springs of the Ichetucknee River, $\mathrm{O}_{2}$ concentrations were positively correlated with $\mathrm{NO}_{3}^{-}$concentrations (Fig. 3a). Across all springs, $\mathrm{O}_{2}$ concentrations were negatively correlated with $\delta^{15} \mathrm{~N}_{\mathrm{NO} 3}$, and negative relationships were also observed over time within low- $\mathrm{O}_{2}$ springs. The apparent absence of $\mathrm{O}_{2}$ driven variation within springs for $\left[\mathrm{N}_{2}\right]_{\mathrm{den}}$ and $\left[\mathrm{NO}_{3}^{-}\right]_{\mathrm{R}}$ is most likely attributable to low power in our data set for those variables and lower precision in estimates of $\left[\mathrm{N}_{2}\right]_{\text {den }}$ (and thus $\left[\mathrm{NO}_{3}^{-}\right]_{\mathrm{R}}$ ) than for $\delta^{15} \mathrm{~N}_{\mathrm{NO} 3}$. Given the strength of observed relationships across springs between denitrification progression and $\delta^{15} \mathrm{~N}_{\mathrm{NO} 3}$, the most likely explanation for within-spring $\delta^{15} \mathrm{~N}_{\mathrm{NO} 3}-\mathrm{O}_{2}$ relationships (Fig. 7) is that variation in both $\mathrm{O}_{2}$ and $\delta^{15} \mathrm{~N}_{\mathrm{NO} 3}$ reflect differential contributions of young and old groundwater (Toth and Katz, 2006). In the former, isotopic signatures are likely unaltered by denitrification; in the latter, depletion of nitrate by denitrification under anoxic conditions would enrich $\delta^{15} \mathrm{~N}_{\mathrm{NO} 3}$ signatures (Kendall et al., 2007). 
A plausible alternative hypothesis is that $\mathrm{O}_{2}-\delta^{15} \mathrm{~N}_{\mathrm{NO}}$ relationships reflect the concurrent influence of humanor animal-derived effluent on dissolved $\mathrm{O}_{2}$ (via increased BOD) and $\delta^{15} \mathrm{~N}_{\mathrm{NO} 3}$. However, if coincident BOD and $\delta^{15} \mathrm{~N}$ enriched $\mathrm{NO}_{3}^{-}$inputs were responsible for these patterns, then high- $\mathrm{O}_{2}$ springs would exhibit covariation between $\mathrm{O}_{2}$ and $\delta^{15} \mathrm{~N}_{\mathrm{NO} 3}$, as is observed in low- $\mathrm{O}_{2}$ springs. Thus, while alternative explanations might plausibly explain some of the pairwise correlations observed in this study (e.g. organic waste inputs as a driver of both $\mathrm{O}_{2}$ and $\delta^{15} \mathrm{~N}_{\mathrm{NO} 3}$ ), the convergence of multiple lines of evidence clearly indicates that groundwater denitrification is a significant process in north Florida, as both a sink for $\mathrm{N}$ inputs and as a driver of variation in isotope signatures.

\subsection{Magnitude and mechanisms of nitrate reduction}

An important feature of this study is that springs integrate upgradient $\mathrm{N}$ transformations over considerable spatial domains and over the entire duration of water residence in the subsurface. In combination with the large spatial extent of our study springs, this feature of springs enables relatively simple scaling of groundwater denitrification to springshed and regional scales. Studies of aquifer denitrification generally address denitrification along individual flowpaths with relatively small spatial footprints, and as such may not reflect the distribution of rates or residence times within the larger aquifer.

At the scale of the UFA, denitrification appears to be a significant sink for $\mathrm{N}$ leaching to the Upper Floridan Aquifer, removing approximately $32 \%$ of the total (flow-weighted) $\mathrm{N}$ discharging from sampled springs. Average volumetric rates derived from $\left[\mathrm{N}_{2}\right]_{\text {den }}$ were toward the low end of values obtained from direct measurement of $\mathrm{N}_{2}$, but were within the range reported for agriculturally enriched aquifers with even higher $\mathrm{NO}_{3}^{-}$concentrations (Green et al., 2008). Nonethless, aggregate areal rates of denitrification $\left(122 \mathrm{~kg} \mathrm{~km}^{2} \mathrm{yr}^{-1}\right)$ are comparable to the estimated global average for aquifer denitrification (Seitzinger et al., 2006). These averages, however, integrate a high degree of variation among springs. Average areal rates for individual springs ranged from less than 0 to as high as $5300 \mathrm{~kg} \mathrm{~km}^{2} \mathrm{yr}^{-1}$, and the depletion of $\mathrm{NO}_{3}^{-}$load from 0 to more than $97 \%$. Thus within the Floridan Aquifer we observe variation in denitrification comparable to that observed globally (Seitzinger et al., 2006). Significant spatial heterogeneity of denitrification has been observed in other aquifers, but none to our knowledge have measured denitrification directly over the spatial and temporal extent found in this study. Our results suggest that measurements along individual groundwater flowpaths are unlikely to be applicable to entire regional aquifer systems.

The occurrrence and significance of denitrification in the organic-matter-poor Floridan Aquifer is superficially suprising, given the importance of organic matter supply as a constraint on denitrification across diverse ecosystem types.
However, several recent studies have found isotopic evidence for denitrification in karstic aquifers, including those in southwestern Illinois, USA (Panno et al., 2001), southern Germany (Einsiedl and Mayer, 2006), and the Floridan Aquifer (Albertin et al., 2011). One feature of karst aquifers that may facilitate denitrification is large difference in hydraulic conductivity, and thus water age and chemistry, between karstic aquifer matrices and conduits. McCallum et al. (2008) showed that mixing of groundwaters of different ages, $\mathrm{NO}_{3}^{-}$concentrations, and redox potentials can promote aquifer denitrification, and such oxic-anoxic interfaces are widely recognized as locations of significant biogeochemical reactivity in surface waters (Dahm et al., 1998) and groundwaters (McMahon, 2001). Similar phenomena might be occurring throughout the considerable surface area of the conduit-matrix interface in karstic systems, and its occurrence and distribution might vary sufficiently to generate the observed differences in denitrification among UFA springs.

The source and character of electron donors that fuel nitrate reduction in the UFA are not known. Low DOC concentrations in UFA springs could imply that denitrification is fueled by some other source, but availability of labile DOC is likely to be higher in water entering the aquifer than in water discharging from springs. Runoff entering sinkholes provide one pathway for relatively labile carbon to enter karstic aquifers, in either dissolved or particulate form. In some cases backflow from C-rich surface waters influences the chemistry of springs discharge (Gulley et al., 2011), and anthropogenic carbon from septic, municipal, or agricultural waste might also provide labile $\mathrm{C}$ to the UFA. That DOC from surface soils and vegetation is degraded after delivery to the UFA is supported by the inverse relationship observed between DOC and spring discharge (Duarte et al., 2010), since smaller springs are less likely to be connected to older flowpaths. Nonetheless, DOC concentrations in virtually all UFA springs are relatively low. It remains to be determined whether the magnitude of DOC inputs and oxidation could account for some, most, or all of the $\mathrm{O}_{2}$ and $\mathrm{NO}_{3}^{-}$depletion that occurs along UFA flowpaths.

The importance of electron donors other than organic $\mathrm{C}$ for denitrification in the UFA remains unclear, but has been demonstrated through correlational and experimental studies in other aquifers, including some karstic systems. Although the carbonate Floridan Aquifer matrix itself is generally poor in minerals that might serve as terminal electron donors, Florida springs exhibit significant variation in mineral chemistry (Scott et al., 2004), and many springsheds include the clay-rich Hawthorn Formation (Wicks and Herman, 1994). If such alternative electron donors drive variation in denitrification among UFA springs, then concentrations of solutes such as $\mathrm{Fe}$ or $\mathrm{SO}_{4}^{2-}$ should be correlated with denitrification. The role of different nitrate reduction pathways, as well as broader drivers such as hydrogeology, geochemistry, and land use as factors that influence denitrification in 
the UFA, are beyond the scope of this paper, but clearly worthy of further investigation.

\subsection{Uncertainty in estimates of denitrification}

Use of dual noble gas tracers $(\mathrm{Ne}, \mathrm{Ar})$ to estimate recharge temperature and excess air produced estimates that were more precise and more accurate than those derived from statistical modeling of excess air. Among springs with $\mathrm{O}_{2}$ greater than $2 \mathrm{mg} \mathrm{L}^{-1}$ and thus presumably negligible denitrification, $\left[\mathrm{N}_{2}\right]_{\text {den }}$ estimates based on dual tracers averaged $0.003 \mathrm{mg} \mathrm{N} \mathrm{L}^{-1}\left(0.1 \mu \mathrm{mol} \mathrm{N} \mathrm{L}^{-1}\right)$ with a standard deviation of $0.32 \mathrm{mg} \mathrm{N} \mathrm{L}^{-1}\left(11.6 \mu \mathrm{mol} \mathrm{N}_{2} \mathrm{~L}^{-1}\right)$. For observations from high $\mathrm{O}_{2}$ springs where $\mathrm{Ne}$ data were unavailable, $\left[\mathrm{N}_{2}\right]_{\text {den }}$ estimates based on statistically modeled excess air averaged $0.32 \mathrm{mg} \mathrm{N}_{2} \mathrm{~L}^{-1}\left(11.6 \mu \mathrm{mol} \mathrm{N}_{2} \mathrm{~L}^{-1}\right)$ with a standard deviation of $16.8 \mu \mathrm{mol} \mathrm{N} \mathrm{N}_{2} \mathrm{~L}^{-1}$. For $\left[\mathrm{N}_{2}\right]_{\text {den }},\left[\mathrm{NO}_{3}^{-}\right]_{\mathrm{R}}$, and $\delta^{15} \mathrm{~N}_{\mathrm{NO} 3}$, spatial variation among springs was large compared to temporal variation within springs.

The stronger relationship between denitrification progression and $\delta^{15} \mathrm{~N}_{\mathrm{NO} 3}$ for springs with Ne data vs. all springs provides additional evidence for greater precision of these estimates. Greater bias and lower precision of these estimates most likely reflects the variability of excess air entrainment over time among springs, but may also reflect introduction of excess air during sampling, an artifact for which our statistical approach does not account. Nonetheless, uncertainty of our direct and statistically-derived estimates of denitrification compare favorably with bias $\left(5 \mu \mathrm{mol} \mathrm{N} \mathrm{N}^{-1}\right)$ and precision ( $\mathrm{SD}=22 \mu \mathrm{mol} \mathrm{N} \mathrm{N}_{2}^{-1}$ ) in a previous study of denitrification in agricultural aquifers, in which limited spatial extent permitted assumptions of constant recharge temperature within regions, and calculation of excess air from Ar concentrations (Green et al., 2008). The relatively high precision and minimal bias of $\left[\mathrm{N}_{2}\right]_{\text {den }}$ estimates in this study illustrate both the value of dual noble gas tracers and the utility of statistical modeling of physical processes where direct measurements are unavailable. Similar approaches will likely be necessary and useful in evaluating the spatial heterogeneity of denitrification in other aquifers.

Mixing of water of different ages and histories can have substantial effects on apparent rates, thresholds, and fractionation factors of denitrification in groundwaters (Green et al., 2010). Because our areal rates are a mass flux (the product of $\left[\mathrm{N}_{2}\right]_{\mathrm{den}}$ and discharge over springshed area), rather than an inferred volumetric rate (e.g. Green et al., 2008), we believe that these estimates are robust to mixing effects. However, both the $\mathrm{O}_{2}$ thresholds that support denitrification and isotopic changes resulting from $\mathrm{NO}_{3}$ pool depletion are nonlinear and thus potentially subject to mixing effects. Unfortunately, because we lack geochemical end-members within the aquifer, we are unable to quantify these mixing effects on our estimates of these parameters. Qualitatively, the effects of mixing would be to increase the apparent $\mathrm{O}_{2}$ threshold that supports denitrification, and to reduce the slope of the relationship between denitrification progression and $\delta^{15} \mathrm{~N}-$ $\mathrm{NO}_{3}$ (Green et al., 2008). If these mixing effects are significant, then the actual source $\delta^{15} \mathrm{~N}-\mathrm{NO} 3$ of springs $\mathrm{NO}_{3}^{-}$ would be lower, and thus even more distinct from observed values. Thus, our estimates of the effect of denitrification on regional-scale isotope signatures are in all likelihood conservative.

Our approach for estimation of denitrification does not spatially isolate the signal of denitrification occurring within the UFA from that occurring in saturated soil horizons, sinkhole lakes and wetlands, or in overlying geologic strata (e.g. Hackley et al., 2007; Tihansky et al., 1997). Excess $\mathrm{N}_{2}$ produced in such environments, after the last contact of a water parcel with the atmosphere, could certainly contribute to observed accumulation of $\mathrm{N}_{2}$ in springs and groundwaters within the UFA. However, the signal of recent recharge in the UFA tends to be oxic, nitrate-rich water (Arthur et al., 2007), suggesting that reduced surface environments contribute minimally to inflow of excess $\mathrm{N}_{2}$. Moreover, the strong correlations among gaseous and isotopic signatures of denitrification might not be expected if surface environments with the potential for atmospheric exposure were the predominant location of $\mathrm{NO}_{3}^{-}$reduction.

One important implication of the low within-spring variance in $\left[\mathrm{N}_{2}\right]_{\text {den }}$ and $\left[\mathrm{NO}_{3}^{-}\right]_{\mathrm{R}}$ (Fig. 5) is that uncertainty in our regional estimate of the magnitude of denitrification and its effect on $\mathrm{N}$ loads delivered to surface waters is largely influenced by whether or not sampled springs are representative, rather than by uncertainty of estimates within sampled springs. Our population of springs almost certainly overrepresents large springs, since we include more than half of the first magnitude springs in northern Florida, but we found no relationship between spring size and excess $\mathrm{N}_{2}$ (data not shown). It is unclear whether our study oversampled $\mathrm{N}$ rich or $\mathrm{N}$ poor springs, since the distribution of $\mathrm{NO}_{3}^{-}$concentrations in small springs is not known. A second source of uncertainty is the magnitude of diffuse groundwater discharge from the UFA, and the comparability of the chemistry of this discharge to that of springs. On an areal basis, we have almost certainly underestimated denitrification in the UFA because estimates only include discharge from one spring over the area of its springshed. Incorporation of excess $\mathrm{N}_{2}$ fluxes from springs with overlapping springsheds and from diffuse groundwater efflux would increase areal estimates of denitrification, but the magnitude of this bias is not known. It is also unclear whether these unmeasured hydrologic flowpaths have excess $\mathrm{N}_{2}$ concentrations comparable to those of the measured springs. In light of these uncertainties, our estimate of denitrification at the scale of the North Florida portion of the UFA should be viewed as a first approximation.

\subsection{Implications for $\mathrm{N}$ source inference}

Concurrent measurements of dissolved gases, nitrate concentrations and isotopes enabled direct estimation of the absolute 
magnitude and relative progression of denitrification, and their relationship to $\delta^{15} \mathrm{~N}_{\mathrm{NO} 3}$ enrichment (Fig. 8). The strong negative relationships between the size of residual nitrate pools and $\delta^{15} \mathrm{~N}_{\mathrm{NO} 3}$ not only provide evidence for the occurrence of denitrification, but also clearly indicate that denitrification exerts a significant influence on nitrate isotopic composition in the UFA (particularly where dissolved $\mathrm{O}_{2}$ concentrations are $<2 \mathrm{mg} \mathrm{L}^{-1}$ ). These relationships, in turn, allowed us to estimate the isotopic composition of the original source $\mathrm{NO}_{3}^{-}$for each spring. These estimates suggest that $\delta^{15} \mathrm{~N}_{\mathrm{NO} 3}$ of nitrate discharging from UFA springs may in some cases differ substantially from the isotopic signature of the original $\mathrm{N}$ source.

Observed variation in $\delta^{15} \mathrm{~N}_{\mathrm{NO} 3}$ among UFA springs was considerable, ranging from values near zero to more than $20 \%$ o. $\delta^{15} \mathrm{~N}_{\mathrm{NO} 3}$ distributions for springs with denitrification estimates and within the Ichetucknee River springs were similar to that of all springs, but the former was biased towards heavier $\delta^{15} \mathrm{~N}_{\mathrm{NO} 3}$ values, and the latter had a smaller range of values and relatively fewer high values. Nonetheless, the similarity of these distributions suggests that interpretation of our source estimates should be applicable to the broader population of springs. In all three data sets, the largest subset of springs had $\delta^{15} \mathrm{~N}_{\mathrm{NO} 3}$ less than $6 \%$, but in each case more than one-third of springs had $\delta^{15} \mathrm{~N}_{\mathrm{NO} 3}$ greater than $6 \%$. Observed values in springs with $\mathrm{N}_{2-\text { den }}$ estimates were higher than the larger data set that included all springs; more than $50 \%$ of $\mathrm{N}_{2-\text { den }}$ springs had $\delta^{15} \mathrm{~N}_{\mathrm{NO} 3}$ values greater than $6 \%$.

Estimated source $\delta^{15} \mathrm{~N}_{\mathrm{NO} 3}$ signatures from springs with dissolved gas data and from the Ichetucknee River springs time series had distributions that differed from observed values in two important respects. First, mean and median values for estimated sources were lower by ca. $2 \%$ and $1.5 \%$, respectively. Second, the frequency of extremely high $\delta^{15} \mathrm{~N}_{\mathrm{NO} 3}$ values was much lower. Significantly, these estimated source values had distributions similar to those of all springs with $\mathrm{O}_{2}>3 \mathrm{mg} \mathrm{L}^{-1}$, where denitrification is presumably negligible. Together, these observations strongly suggest that most $\delta^{15} \mathrm{~N}_{\mathrm{NO} 3}$ values in UFA springs somewhat overestimate the contribution of organic sources, and in particular that very high values overwhelmingly reflect fractionation resulting from nitrate removal by denitrification, rather than large contributions from organic $\mathrm{N}$ sources.

To date, denitrification has largely been assumed to be negligible in the Upper Floridan Aquifer, and as a result, elevated $\delta^{15} \mathrm{~N}_{\mathrm{NO} 3}$ values have been interpreted as indicating a significant contribution from organic sources. Despite mass balance studies indicating fertilizer application as the dominant $\mathrm{N}$ source to springsheds, policy and management efforts have largely focused on reducing $\mathrm{N}$ inputs from septic tanks, and agricultural and municipal waste (Loper et al., 2005; Dederkorkut, 2005; Mattson et al., 2006), largely on the basis of enriched $\delta^{15} \mathrm{~N}_{\mathrm{NO} 3}$ signatures. Our data suggest that interpretation of $\delta^{15} \mathrm{~N}_{\mathrm{NO} 3}$ values must account for fractionating $\mathrm{N}$ transformations within the aquifer.

As one example of the effects of fractionation, Wekiwa springs, near Orlando FL, has a heavily urbanized catchment and consistently elevated $\delta^{15} \mathrm{~N}_{\mathrm{NO} 3}$ values (mean of 4 observations from 2001-2010: $11.5 \pm 3.1 \%$ ), which would initially suggest that elevated $\mathrm{NO}_{3}^{-}$concentrations in that system are primarily derived from organic sources. However, $\delta^{18} \mathrm{O}_{\mathrm{NO} 3}$ are also highly enriched $(12.4 \%$ ) , and measurements of $\mathrm{N}_{2-\text { den }}$ are consistently high (mean of 4 observations from 2001-2010: $3.1 \pm 0.4 \mathrm{mg} \mathrm{N}_{2} \mathrm{~L}^{-1}$ ). We estimate that denitrification within the aquifer typically removes ca. $75 \%$ of $\mathrm{NO}_{3}^{-}$before discharge from Wekiwa springs, and that the original source of nitrate in Wekiwa Springs had a $\delta^{15} \mathrm{~N}_{\mathrm{NO}}$ value ca. $6.3 \%$. While individual estimates of source $\delta^{15} \mathrm{~N}_{\mathrm{NO} 3}$ should be viewed with caution, it seems likely that despite its urban setting, $\mathrm{N}$ enrichment of Wekiwa springs is due primarily to inorganic fertilizers, with contributions from organic sources. In contrast, Wakulla Springs, near Tallahassee, FL, has somewhat enriched $\delta^{15} \mathrm{~N}_{\mathrm{NO} 3}$ (6.4$7.9 \%$ ) but no excess $\mathrm{N}_{2}$. Moreover, hydrologic tracer studies have demonstrated direct connections between the Tallahassee municipal waste sprayfield and Wakulla Springs (Kincaid et al., 2005). Thus, it seems safe to conclude that elevated $\delta^{15} \mathrm{~N}_{\mathrm{NO} 3}$ values in Wakulla springs do in fact reflect the isotopic signature of $\mathrm{N}$ sources, which include significant contributions from organic sources. However, our observations suggest that this is the exception rather than the rule. Absent direct evidence for substantial organic sources for a specific spring, efforts to reduce $\mathrm{N}$ loading to the UFA should focus on fertilizer inputs.

\section{Conclusions}

The importance of denitrification for $\mathrm{N}$ fluxes and isotopic composition in the UFA has important implications both for management of North Florida landscapes and for broader understanding of groundwater denitrification. Methodologically, this study illustrates the value of multiple lines of inference for assessing denitrification, which are strengthened by direct estimates of the physical processes that influence $\mathrm{N}_{2}$ concentration using multiple tracers. Significant spatial and temporal variability of denitrification within the UFA suggests that improving regional and global estimates of denitrification will require more extensive measurements in other aquifers. The variability of denitrification in the Upper Floridan Aquifer has implications not only for regional estimates of $\mathrm{N}$ removal, but also for values and variability of isotopic signatures of residual nitrate pools at the regional scale. Accurate assessments of the contribution of various sources of $\mathrm{N}$ enrichment, in North Florida and elsewhere, must account for the influence of denitrification on $\mathrm{N}$ isotope ratios. 


\section{Supplementary material related to this article is available online at: http://www.biogeosciences.net/9/ 1671/2012/bg-9-1671-2012-supplement.zip.}

Acknowledgements. The authors wish to thank Larry Kohrnak and Chad Foster for their help with field sampling, and Steve Walsh, Sharon Kroenig, and Leel Knowles for sharing data. S.V. Panno, K.C. Hackley, Pete McMahon, and two anonymous reviewers provided insightful comments that helped clarify many aspects of this paper. This research was supported by grants from the St. Johns River Water Management District, the Southwest Florida Water Management District, the Three Rivers Foundation, and the National Science Foundation (EAR 0838390). The conclusions in this paper are those of the authors and do not necessarily reflect the views or policy of any state or federal agency.

Edited by: C. P. Slomp

\section{References}

Albertin, A. R., Sickman, J. O., Pinowska, A., and Stevenson, R. J.: Identification of nitrogen sources and transformations within karst springs using isotope tracers of nitrogen, Biogeochemistry, 108, 219-232, doi:10.1007/s10533-011-9592-0, 2011.

APHA, AWWA, and WEF: Standard methods for the examination of water and wastewater, 21st ed., American Public Health Association, Washington, DC, 2005.

Aravena, R. and Robertson, W. D.: Use of multiple isotope tracers to evaluate denitrification in ground water: Study of nitrate from a large-flux septic system plume, Ground Water, 36, 975-982, 1998.

Arthur, J. D., Wood, H. A. R., Baker, A. E., Cichon, J. R., and Raines, G. L.: Development and implementation of a bayesianbased aquifer vulnerability assessment in Florida, Natural Resources Research, 16, 93-107, 2007.

Bedard-Haughn, A., van Groenigen, J. W., and van Kessel, C.: Tracing N-15 through landscapes: Potential uses and precautions, J. Hydrol., 272, 175-190, 2003.

Bohlke, J. K., Wanty, R., Tuttle, M., Delin, G., and Landon, M.: Denitrification in the recharge area and discharge area of a transient agricultural nitrate plume in a glacial outwash sand aquifer, Minnesota, Water Resour. Res., 38, 1105-1130, doi:110510.1029/2001wr000663, 2002.

Bonn, M. A.: Visitor profiles, economic impacts and recreational aesthetic values associated with eight priority Florida springs located in the St. Johns River Water Management District, St. Johns River Water Management District, Palatka, FL, 136 pp., 2004.

Bonn, M. A. and Bell, F. W.: Economic impact of selected Florida springs on surrounding local areas., Florida Department of Environmental Protection, Tallahassee, Florida, USA, 99 pp., 2003.

Burgin, A. J. and Hamilton, S. K.: Have we overemphasized the role of denitrification in aquatic ecosystems? A review of nitrate removal pathways, Front. Ecol. Environ., 5, 89-96, 2007.

Burns, D. A., Boyer, E. W., Elliott, E. M., and Kendall, C.: Sources and transformations of nitrate from streams draining varying land uses: Evidence from dual isotope analysis, J. Environ. Qual., 38, 1149-1159, doi:10.2134/jeq2008.0371, 2009.

Casciotti, K. L., Sigman, D. M., Hastings, M. G., Bohlke, J. K., and Hilkert, A.: Measurement of the oxygen isotopic composition of nitrate in seawater and freshwater using the denitrifier method, Anal. Chem., 74, 4905-4912, doi:10.1021/ac020113w, 2002.

Castro, M. C., Hall, C. M., Patriarche, D., Goblet, P., and Ellis, B. R.: A new noble gas paleoclimate record in Texas - basic assumptions revisited, Earth Planet. Sc. Lett., 257, 170-187, doi:10.1016/j.eps1.2007.02.030, 2007.

Cey, B. D., Hudson, G. B., Moran, J. E., and Scanlon, B. R.: Evaluation of noble gas recharge temperatures in a shallow unconfined aquifer, Ground Water, 47, 646-659, doi:10.1111/j.17456584.2009.00562.x, 2009.

Chapelle, F. H., McMahon, P. B., Dubrovsky, N. M., Fujii, R. F., Oaksford, E. T., and Vroblesky, D. A.: Deducing the distribution of terminal electron-accepting processes in hydrologically diverse groundwater systems, Water Resour. Res., 31, 359-371, doi:10.1029/94wr02525, 1995.

Cohen, M. J., Heffernan, J. B., Albertin, A. A., and Martin, J. B.: Inference of riverine nitrogen processing from longitudinal and diel variation in dual nitrate isotopes, J. Geophys. Res.-Biogeosci., 117, G01021, doi:10.1029/2011JG001715, 2012.

Dahm, C. N., Grimm, N. B., Marmonier, P., Valett, H. M., and Vervier, P.: Nutrient dynamics at the interface between surface waters and groundwaters, Freshwater Biol., 40, 427-451, 1998.

David, M. B., Wall, L. G., Royer, T. V., and Tank, J. L.: Denitrification and the nitrogen budget of a reservoir in an agricultural landscape, Ecol. Appl., 16, 2177-2190, 2006.

Davidson, E. A. and Seitzinger, S.: The enigma of progress in denitrification research, Ecol. Appl., 16, 2057-2063, 2006.

Dederkorkut, A.: Suwanee River Partnership: Representation instead of regulation, in: Adaptive Governance and Water Conflict: New Institutions for Collaborative Planning, edited by: Scholz, J. and Stiftel, B., Resources for the Future Press, Washington, DC, 25-39, 2005.

Duarte, C. M., Prairie, Y. T., Frazer, T. K., Hoyer, M. V., Notestein, S. K., Martínez, R., Dorsett, A., and Canfield, D. E.: Rapid accretion of dissolved organic carbon in the springs of Florida: the most organic-poor natural waters, Biogeosciences, 7, 40514057, doi:10.5194/bg-7-4051-2010, 2010.

Einsiedl, F. and Mayer, B.: Hydrodynamic and microbial processes controlling nitrate in a fissured-porous karst aquifer of the Franconian Alb, southern Germany, Environ. Sci. Technol., 40, 6697 6702, doi:10.1021/es061129x, 2006.

Eyre, B. D., Rysgaard, S., Dalsgaard, T., and Christensen, P. B.: Comparison of isotope pairing and N-2: Ar methods for measuring sediment-denitrification-assumptions, modifications, and implications, Estuaries, 25, 1077-1087, 2002.

Feast, N. A., Hiscock, K. M., Dennis, P. F., and Andrews, J. N.: Nitrogen isotope hydrochemistry and denitrification within the chalk aquifer system of North Norfolk, UK, J. Hydrol., 211, 233252, 1998.

Fogg, G. E., Rolston, D. E., Decker, D. L., Louie, D. T., and Grismer, M. E.: Spatial variation in nitrogen isotope values beneath nitrate contamination sources, Ground Water, 36, 418-426, 1998.

Galloway, J. N., Aber, J. D., Erisman, J. W., Seitzinger, S. P., Howarth, R. W., Cowling, E. B., and Cosby, B. J.: The nitrogen cascade, Bioscience, 53, 341-356, 2003. 
Granger, J., Sigman, D. M., Lehmann, M. F., and Tortell, P. D.: Nitrogen and oxygen isotope fractionation during dissimilatory nitrate reduction by denitrifying bacteria, Limnol. Oceanogr., 53, 2533-2545, 2008.

Green, C. T., Puckett, L. J., Bohlke, J. K., Bekins, B. A., Phillips, S. P., Kauffman, L. J., Denver, J. M., and Johnson, H. M.: Limited occurrence of denitrification in four shallow aquifers in agricultural areas of the United States, J. Environ. Qual., 37, 994-1009, doi:10.2134/jeq2006.0419, 2008.

Green, C. T., Bohlke, J. K., Bekins, B. A., and Phillips, S. P.: Mixing effects on apparent reaction rates and isotope fractionation during denitrification in a heterogeneous aquifer, Water Resourc. Res., 46, W08525, doi:10.1029/2009wr008903, 2010.

Groffman, P. M., Butterbach-Bahl, K., Fulweiler, R. W., Gold, A. J., Morse, J. L., Stander, E. K., Tague, C., Tonitto, C., and Vidon, P.: Challenges to incorporating spatially and temporally explicit phenomena (hotspots and hot moments) in denitrification models, Biogeochemistry, 93, 49-77, doi:10.1007/s10533-008-92775, 2009.

Gulley, J., Martin, J. B., Screaton, E. J., and Moore, P. J.: River reversals into karst springs: A model for cave enlargement in eogenetic karst aquifers, Geol. Soc. Am. Bull., 123, 457-467, doi:10.1130/b30254.1, 2011.

Hackley, K. C., Panno, S. V., Hwang, H. H., and Kelly, W. R.: Groundwater quality of springs and wells of the sinkhole plain in Southwestern Illinois: Determination of the dominant sources of nitrate, Illinois Geological Survey, Circular, 570, 2007.

Hall, C. M., Castro, M. C., Lohmann, K. C., and Ma, L.: Noble gases and stable isotopes in a shallow aquifer in southern Michigan: Implications for noble gas paleotemperature reconstructions for cool climates, Geophys. Res. Lett., 32, 4, L18404, doi:10.1029/2005g1023582, 2005.

Hamme, R. C. and Emerson, S. R.: The solubility of neon, nitrogen and argon in distilled water and seawater, Deep-Sea Research Part I-Oceanographic Research Papers, 51, 1517-1528, doi:10.1016/j.dsr.2004.06.009, 2004.

Harms, T. K. and Grimm, N. B.: Hot spots and hot moments of carbon and nitrogen dynamics in a semiarid riparian zone, J. Geophys. Res.-Biogeo., 113, G01020, 2008.

Harrington, D., Maddox, G., and Hicks, R.: Florida springs initiative monitoring network report and recognized sources of nitrate, Florida Department of Environmental Protection, Tallahassee, FL, 103, 2010.

Hedin, L. O., von Fischer, J. C., Ostrom, N. E., Kennedy, B. P., Brown, M. G., and Robertson, G. P.: Thermodynamic constraints on nitrogen transformations and other biogeochemical processes at soil-stream interfaces, Ecology, 79, 684-703, 1998.

Heffernan, J. B., Cohen, M. J., Frazer, T. K., Thomas, R., Rayfield, T., Gulley, J., Martin J. B., Delfino, J. J., and Graham, W. D.: Hydrologic and biotic influences on nitrate removal in a subtropical spring-fed river, Limnol. Oceanogr., 55, 249-263, 2010a.

Heffernan, J. B., Liebowitz, D. L., Frazer, T. K., Evans, J. M., and Cohen, M. J.: Algal blooms and the nitrogen-enrichment hypothesis in Florida springs: Evidence, alternatives, and adaptive management, Ecol. Appl., 20, 816-829, 2010b.

Kana, T. M., Darkangelo, C., Hunt, M. D., Oldham, J. B., Bennett, G. E., and Cornwell, J. C.: Membrane inlet mass-spectrometer for rapid high-precision determination of N-2, O-2, and $\mathrm{Ar}$ in environmental water samples, Anal. Chem., 66, 4166-4170, 1994.
Katz, B. G.: Sources of nitrate contamination and age of water in large karstic springs of Florida, Environ. Geol., 46, 689-706, 2004.

Katz, B. G., Bohlke, J. K., and Hornsby, H. D.: Timescales for nitrate contamination of spring waters, northern Florida, USA, Chem. Geol., 179, 167-186, 2001.

Katz, B. G., Chelette, A. R., and Pratt, T. R.: Use of chemical and isotopic tracers to assess nitrate contamination and groundwater age, Woodville Karst Plain, USA, J. Hydrol., 289, 36-61, doi:10.1016/j.hydrol.2003.11.001, 2004.

Katz, B. G., Sepulveda, A. A., and Verdi, R. J.: Estimating nitrogen loading to ground water and assessing vulnerability to nitrate contamination in a large karstic springs basin, Florida, J. Am. Water Resour. As., 45, 607-627, doi:10.1111/j.17521688.2009.00309.x, 2009.

Kendall, C.: Tracing nitrogen sources and cycling in catchments, in: Isotope tracers in catchment hydrology, edited by: Kendall, C., and McDonnell, J. J., Elsevier Science B.V., Amsterdam, The Netherlands, 1998.

Kendall, C. and Grim, E.: Combustion tube method for measurement of nitrogen isotope ratios using calcium-oxide for total removal of carbon-dioxide and water, Anal. Chem., 62, 526-529, 1990.

Kendall, C., Elliott, E. M., and Wankel, S. D.: Tracing anthropogenic inputs of nitrogen to ecosystems, in: Stable isotopes in ecology and environmental science, edited by: Michener, R. H. and Lajtha, K., Wiley - Blackwell Publishing, Malden, MA, 375-449, 2007.

Kincaid, T. R., Hazlett, T. J., and Davies, G. J.: Quantitative groundwater tracing and effective numerical modeling in karst: an example from the Woodville Karst Plain of North Florida, in: Sinkholes and the Engineering and Environmental Impacts of Karst: Reston, VA, edited by: Beck, B. F., American Society of Civil Engineers, 114-121, 2005.

Knoller, K., Vogt, C., Haupt, M., Feisthauer, S., and Richnow, H. H.: Experimental investigation of nitrogen and oxygen isotope fractionation in nitrate and nitrite during denitrification, Biogeochemistry, 103, 371-384, doi:10.1007/s10533-010-9483-9, 2011.

Knowles, L., Katz, B. G., and Toth, D. J.: Using multiple chemical indicators to characterize and determine the age of groundwater from selected vents of the Silver Springs group, central Florida, USA, Hydrogeol. J., 18, 1825-1838, doi:10.1007/s10040-0100669-y, 2010.

Lehmann, M. F., Reichert, P., Bernasconi, S. M., Barbieri, A., and McKenzie, J. A.: Modelling nitrogen and oxygen isotope fractionation during denitrification in a lacustrine redoxtransition zone, Geochim. Cosmochim. Ac., 67, 2529-2542, doi:10.1016/s0016-7037(03)00085-1, 2003.

Loper, D., Landing, W., Pollman, C. , and Chan Hilton, A.: Degradation of water quality at Wakulla Springs, FL: Assessment and recommendations, Report of the Peer Review Committee on the Workshop Solving Water Pollution Problems in the Wakulla Springshed of North Florida. Florida Department of Environmental Protection, Tallahassee, FL, 70 pp., 2005.

Mariotti, A.: Denitrification in groundwaters, principles and methods for its identification - a review, J. Hydrol., 88, 1-23, 1986.

Martin, J. B. and Dean, R. W.: Exchange of water between conduits and matrix in the Floridan Aquifer, Chem. Geol., 179, 145-165, 
2001.

Mattson, R. A., Lowe, E. F., Lippincott, C. L., Di, J., and Battoe, L.: Wekiva River and Rock Springs Run Pollutant Load Reduction Goals, Florida Department of Environmental Protection, Tallahassee, FL, 69 pp., 2006.

McCallum, J. E., Ryan, M. C., Mayer, B., and Rodvang, S. J.: Mixing-induced groundwater denitrification beneath a manured field in southern Alberta, Canada, Appl. Geochem., 23, 21462155, doi:10.1016/j.apgeochem.2008.03.018, 2008.

McMahon, P. B.: Aquifer/aquitard interfaces: Mixing zones that enhance biogeochemical reactions, Hydrogeol. J., 9, 34-43, doi:10.1007/s100400000109, 2001.

McMahon, P. B. and Bolke, J. K.: Regional patterns in the isotopic composition of natural and anthropogenic nitrate in groundwater, high plains, USA, Environ. Sc. Technol., 40, 2965-2970, doi:10.1021/es052229q, 2006.

Miller, J. A.: Ground water atlas of the United States; Alabama, Florida, Georgia, and South Carolina., Hydrologic atlas, U.S. Geological Survey, HA730-G, 1990.

Notholt, A. J. G., Sheldon, R. P., and Davidson, D. F.: North America and Greenland-introduction, in: Phosphate deposits of the world; Volume 2-Phosphate rock resources: Cambridge, edited by: Notholt, A. J. G., Sheldon, R. P., and Davidson, D. F., Cambridge University Press, 90-94, 1989.

Panno, S. V., Hackley, K. C., Hwang, H. H., and Kelly, W. R.: Determination of the sources of nitrate contamination in karst springs using isotopic and chemical indicators, Chem. Geol., 179, 113128,2001

Pittman, J. R., Hatzell, H. H., and Oaksford, E. T.: Spring contributions to water quality and nitrate loads in the Suwannee River during baseflow in July 1995, U. S. Geological Survey WaterResources Investigations Report 97-4152, Reston, VA, 1997.

Schlesinger, W. H.: On the fate of anthropogenic nitrogen, Proceedings of the National Academy of Sciences of the United States of America, 106, 203-208, doi:10.1073/pnas.0810193105, 2009.

Schmidt, N., Lipp, E. K., Rose, J. B., and Luther, M. E.: Enso influences on seasonal rainfall and river discharge in Florida, Journal of Climate, 14, 615-628, doi:10.1175/15200442(2001)014<0615:eiosra > 2.0.co;2, 2001.

Schwientek, M., Einsiedl, F., Stichler, W., Stogbauer, A., Strauss, H., and Maloszewski, P.: Evidence for denitrification regulated by pyrite oxidation in a heterogeneous porous groundwater system, Chem. Geol., 255, 60-67, doi:10.1016/j.chemgeo.2008.06.005, 2008.

Scott, T. M., Means, G. H., Meegan, R. P., Means, R. C., Upchurch, S. B., Copeland, R. E., Jones, J., Roberts, T., and Willet, A.: Springs of Florida, Florida Geological Survey Bulletin 66, Tallahassee, FL, 347 pp., 2004.

Sebilo, M., Billen, G., Grably, M., and Mariotti, A.: Isotopic composition of nitrate-nitrogen as a marker of riparian and benthic denitrification at the scale of the whole Seine River system, Biogeochemistry, 63, 35-51, 2003.

Seitzinger, S., Harrison, J. A., Bohlke, J. K., Bouwman, A. F., Lowrance, R., Peterson, B., Tobias, C., and Van Drecht, G.: Denitrification across landscapes and waterscapes: A synthesis, Ecol. Appl., 16, 2064-2090, 2006.

Sigman, D. M., Casciotti, K. L., Andreani, M., Barford, C., Galanter, M., and Bohlke, J. K.: A bacterial method for the nitrogen isotopic analysis of nitrate in seawater and freshwater, Anal.
Chem., 73, 4145-4153, 2001.

Sigman, D. M., Granger, J., DiFiore, P. J., Lehmann, M. M., Ho, R., Cane, G., and van Geen, A.: Coupled nitrogen and oxygen isotope measurements of nitrate along the eastern North Pacific margin, Global Biogeochem. Cy., 19, GB4022, doi:10.1029/2005gb002458, 2005.

Sigman, D. M., DiFiore, P. J., Hain, M. P., Deutsch, C., Wang, Y., Karl, D. M., Knapp, A. N., Lehmann, M. F., and Pantoja, S.: The dual isotopes of deep nitrate as a constraint on the cycle and budget of oceanic fixed nitrogen, Deep-Sea Res. Pt. I, 56, 1419 1439, doi:10.1016/j.dsr.2009.04.007, 2009.

Smith, V. H. and Schindler, D. W.: Eutrophication science: Where do we go from here?, Trends Ecol. Evol., 24, 201-207, doi:10.1016/j.tree.2008.11.009, 2009.

Tarits, C., Aquilina, L., Ayraud, V., Pauwels, H., Davy, P., Touchard, F., and Bour, O.: Oxido-reduction sequence related to flux variations of groundwater from a fractured basement aquifer (Ploemeur area, France), Appl. Geochem., 21, 29-47, doi:10.1016/j.apgeochem.2005.09.004, 2006.

Taylor, P. G. and Townsend, A. R.: Stoichiometric control of organic carbon-nitrate relationships from soils to the sea, Nature, 464, 1178-1181, doi:10.1038/nature08985, 2010.

Tihansky, A. B. and Sacks, L. A.: Evaluation of nitrate sources using nitrogen-isotope techniques in shallow ground water within selected lake basins in the Central Lakes District, Polk and Highlands Counties, Florida, US Geological Survey, Reston, VA, Water-Resources Investigations Report 97-4207, 1997.

Torrento, C., Cama, J., Urmeneta, J., Otero, N., and Soler, A.: Denitrification of groundwater with pyrite and thiobacillus denitrificans, Chem. Geol., 278, 80-91, doi:10.1016/j.chemgeo.2010.09.003, 2010.

Torrento, C., Urmeneta, J., Otero, N., Soler, A., Vinas, M., and Cama, J.: Enhanced denitrification in groundwater and sediments from a nitrate-contaminated aquifer after addition of pyrite, Chem. Geol., 287, 90-101, doi:10.1016/j.chemgeo.2011.06.002, 2011.

Toth, D. J. and Katz, B. G.: Mixing of shallow and deep groundwater as indicated by the chemistry and age of karstic springs, Hydrogeol. J., 14, 827-847, doi:10.1007/s10040-005-0478-x, 2006.

Townsend, A. R. and Davidson, E. A.: Denitrification across landscapes and waterscapes, Ecol. Appl., 16, 2055-2056, 2006.

Upchurch, S. B., Chen, J., and Cain, C. R.: Trends of nitrate concentrations in waters of thesuwannee river water management district, 2007, Suwannee River Water Management District, Live Oak, FL, 2007.

USGS (US Geological Survey): Nutrients in the Upper Mississippi River: Scientific information to support management decisions, USGS Fact Sheet 6, 2003.

Vitousek, P. M.: Beyond global warming - ecology and global change, Ecology, 75, 1861-1876, 1994.

Vogel, J. C., Talma, A. S., and Heaton, T. H. E.: Gaseous nitrogen as evidence for denitrification in groundwater, J. Hydrol., 50, 191200, doi:10.1016/0022-1694(81)90069-x, 1981.

Wicks, C. M. and Herman, J. S.: The effect of a confining unit on the geochemical evolution of groundwater in the Upper Floridan Aquifer system, J. Hydrol., 153, 139-155, doi:10.1016/00221694(94)90189-9, 1994.

Wilson, G. B. and McNeill, G. W.: Noble gas recharge temperatures and the excess air component, Appl. Geochem., 12, 747-762, 
doi:10.1016/s0883-2927(97)00035-8, 1997.

Wood, E. D., Armstrong, F. A. J., and Richards, F. A.: Determination of nitrate in sea water by cadmium-copper reduction to nitrite, J. Marine Biol. Assoc. UK, 47, 31-43, 1967.
Zhang, Y. C., Slomp, C. P., Broers, H. P., Passier, H. F., and Van Cappellen, P.: Denitrification coupled to pyrite oxidation and changes in groundwater quality in a shallow sandy aquifer, Geochim. Cosmochim. Ac., 73, 6716-6726, doi:10.1016/j.gca.2009.08.026, 2009. 